\title{
SRTC Monthly Report, May 1995
}

by

J. M. Forrell

Westinghouse Savannah River Company

Savannah River Site

Aiken, South Carolina 29808

This paper was prepared in connection with work done under the above contract number with the U. S. Department of Energy. By acceptance of this paper, the publisher and/or recipient acknowledges the U.S. Government's right to retain a nonexclusive, royalty-free license in and to any copyright covering this paper, along with the right to reproduce and to authorize others to reproduce all or part of the copyrighted paper. 
WSRC-TR-95-100-5

\section{Savannah River Technology Center Monthly Report}

May 1995

Westinghouse Savannah River Company

Savannah River Site

Aiken, SC 29808

Prepared for the U.S. Department of Energy under contract no. DE-AC09-89SR18035 


\section{DISCLAIMER}

This report was prepared as an account of work sponsored by an agency of the United States Government. Neither the United States Government nor any agency thereof, nor any of their employees, makes any warranty, express or implied, or assumes any legal liability or responsibility for the accuracy, completeness, or usefulness of any information, apparatus, product, or process disclosed, or represents that its use would not infringe privately owned rights. Reference herein to any specific commercial product, process, or service by trade name, trademark, manufacturer, or otherwise does not necessarily constitute or imply its endorsement, recommendation, or favoring by the United States Government or any agency thereof. The views and opinions of authors expressed herein do not necessarily state or reflect those of the United States Government or any agency thereof.

This report has been reproduced directly from the best available copy.

Available to DOE and DOE contractors from the Office of Scientific and Technical Information, P.O. Box 62, Oak Ridge, TN 37831; prices available from (615) 576-8401.

Available to the public from the National Technical Information Service, U.S. Department of Commerce, 5285 Port Royal Road, Springfield, VA 22161. 
WSRC-TR-95-100-5

Savannah River Technology Center Monthly Report

May 1995 


\section{Executive Summary}

\section{TRITIUM}

- A total of forty-three pinch welds and nineteen reclamation welds were evaluated in the Materials Test Facility to aid the Tritium Facility in completing the LF-7 Reclamation and Pinch Weld Qualification Plan for the newly designed LF-7 reservoir.

- Metallographic examination of the reclaimed areas of the full scale deuterium-loaded Terrazzo reservoir showed good structure for the laser weld and for the cap weld. The first tritium-exposed fill stem to be laser drilled and laser welded showed some indication of ${ }^{3} \mathrm{He}$ effects in the inner regions of the tube wall which require further investigation.

- A pair of deuterium loaded LF7 reservoirs have been function tested in the Function Test Facility. The purpose of the test was to verify that the new LF7 design and material of construction have no impact on the performance of the unit. Details of the tests are given.

- ADS provided technical assistance for the development of the Tritium Facilities Waste Characterization Plan.

- An analysis has been performed to determine the maximum steady-state surface temperature for a hypothetical tritium reservoir or Hydride Storage Vessel (HSV) stored in the proposed Highly Invulnerable Encased Safe (HIVES). The analysis used mass, momentum, and energy balances to derive expressions for the volumetric flow rate and axial temperature.

- EES completed all as-built record and development drawings for Project 4173 (over 110 drawings total).

- EES is responsible for the design and fabrication of three Kanne skids which will be used in conjunction with the new Environmental Chambers. 
- EES was requested by Separations Engineering to design and fabricate a custom vacuum filter housing to replace the current housings in HBLine.

- The Frame Waste Recovery column is operated as an anion exchange process to recover Pu238 in H-Canyon. Radiolytic heating of Pu238 loaded on the resin makes this column vulnerable to temperature excursions during flow interruptions. At temperatures in the range of 80 to $100^{\circ} \mathrm{C}$, the heat from the chemical reaction between the resin and nitric acid becomes controlling and rate of temperature rise accelerates significantly. A level one confirmed calculation shows that it will take almost 2 hours for the loaded column to heat from $50^{\circ} \mathrm{C}$ to $110^{\circ} \mathrm{C}$ (boiling $8 \mathrm{M}$ nitric acid) and also shows that the gassing rate from the column can be vented without significant pressure rise. This work contributed to the resolution of the SAR inadequacy that recently curtailed $\mathrm{Pu} 238$ processing in $\mathrm{H}$-Canyon.

- The unexplained increase in plutonium solids followed by a decrease in the next sample may be explained by the release of $\mathrm{DBP} / \mathrm{Pu}$ complex from the walls of Tank 9.6. Work is continuing to determine the source of the variation.

- The experimental work and data analyses of the solids-suspension study have been completed. The experimental data were obtained for several different variables that may be adjusted in the plant. A technical report summarizing the findings of the experimental work will be issued jointly with GA Tech Professor A. H. P. Skelland.

- ADS has begun an effort to replace an old spectrophotometer used to service the B-Lines with a newer unit and updated software.

- A set of calculations were performed to estimate the time required to reach the lower flammability limit (LFL) of $4 \%$ hydrogen gas (H-2) in the vapor space of the LR-56 Cask System. Experimental data were used to determine the $\mathrm{G}$ factor for $\mathrm{H}-2$ generation. This was then used to estimate the time required to reach $\mathrm{LFL}$.

- Packaging and Transportation continues efforts toward renewal of the 5320 packaging Certificate of Compliance. Packaging and Transportation completed the first project milestone toward meeting a September 1995 date for submittal of a revised SARP to DOE-SR. The milestone to answer half of the Q1 questions by 4/28/95 was exceeded with $55 \%$ of the questions answered. 


\section{ENVIRONMENTAL}

- As part of the DOE contract negotiations with SCE\&G to privatize the D-Area power house operations, ETG began modeling numerous emissions scenarios to determine what, if any, modifications to powerhouse operations would be required to prevent exceeding the ambient air quality standard if the powerhouse were ever operated at full capacity with the emissions levels allowed by the permit.

- The annual spring overflight of SRS by the EG\&G Remote Sensing Laboratory of DOE was flown. All target areas were successfully completed.

- Nine emissions scenarios for oxides of nitrogen emissions (NOx) from the projected vitrification plant in $\mathrm{M}$ Area were modeled to support a modified air permit application.

- Planting of twelve acres of deep water habitat on the Pen Branch delta was performed by SR Forest Service personnel in April. This completes the major planting program for the reforestation program.

- The TNX has experienced a reduction in benzenes by the Organic Removal Facility (ORF) that far exceeds the adsorption capabilities of the activated carbon. Upon examination, the carbon was found to contain a dense biofilm with large number of bacteria. Isolation of benzene and chlorobenzene degraders from ORF samples is under evaluation.

- Dose modeling of the 1994 environmental radioactive releases was completed. Releases continue their downward trend although the liquid doses were slightly higher because of reduced flow of the Savannah River.

- A final report on the March 23 pollen measurements near H-Area Retention Basin was issued. The dose measured on March 23 was well below the ICRP-recommended de minimis of $2700 \mathrm{nRem} /$ day (1 $\mathrm{mRem} / \mathrm{yr}$ ).

- Support was provided to IWT for evaluating a pilot-scale ion-exchanger facility to remove Cs-137 from L-Area Disassembly Basin. Low-level gamma spectrometry results were reported.

- Dose-release factors were determined in support of the Waste Management Environmental Impact Statement (EIS) for a hypothetical radioactive release at Barnwell, South Carolina, from a shipment of low-level waste.

- A meteorological data set consisting of daily maximum instantaneous wind speeds for 1993 was prepared for the Environmental Protection Department. This data will be used to calculate estimates of emissions from SRS coal storage piles from wind-induced erosion. 
- SRS swamp area hydrology was modeled. Boundary conditions of this simulated case are 12,000 cubic feet per second for the Savannah River flow and 79.5 feet for the river stage at Steel Creek gauge station.

- To improve the capability of the STREAM code to model long-term releases, its calculation module was replaced by the WASP5 code. WASP5 is a U. S. EPA water quality analysis program that simulates one-dimensional pollutant transport through surface water.

- The trace metal analysis of 45 vegetation samples collected at various locations on the Savannah River Site was completed.

- A report on the SRTC's Climatology Site is now available for distribution.

- The well installation and initial soil sampling at both sanitary landfill sites 1 and 2 are complete. A final DHEC site inspection and approval to start the test is scheduled for June 8, 1995.

- The Scout portable 256-channel multichannel analyzer was tested in the field with a $1 " \mathrm{n} 1$ " $\mathrm{NaI}(\mathrm{Tl})$ detector. This system was field tested as part of the RADMAPS project to develop analysis methods for scintillation spectra.

- As part of the industrial assistance prograrn the Biotechnology Group is evaluating the Columbia County Landfill and preparing a list of options that may aid them. It is felt that bioremediation strategies may increase the life of the landfill and allow some areas to be reclaimed or reused.

- A complete set of the technical documentation completed during the SRS Integrated Demonstration for Cleanup of VOC at Non-Arid sites was collated and sent to RAPIC. A short animated video sequence of the data from the bioremediation demonstration completed during the Integrated Demonstration was completed. This sequence simultaneously displays concentrations of microorganisms, concentrations of the primary contaminant TCE, the clay content of the sediments, and chloride concentrations during the in-situ bioremediation demo has been completed.

- The Environmental Technology Section is performing radionuclide analyses of samples collected by the U.S. Geological Survey (USGS) in the Arctic Ocean, and supporting a sampling trip led by the USGS to measure radionuclides in the $\mathrm{Ob}$ and Yenisey Rivers in Russia. Results of high resolution gamma spectrometry analyses of sea ice rafted sediments in the Arctic Ocean show that the sediments originating near the Former Soviet Union (FSU) have significantly more activity than those originating near the Alaskan coast.

- Laboratory tests are nearing completion on extraction of Tc-99 from fresh and seawater using Mag-Sep technology. The kinetics of uptake of Tc-99 from water is very rapid and nearly complete (greater than $98 \%$ uptake within 30 minutes using 1 gram of particles in a 1-liter sample. 
- M.H. Paller was invited to participate in a workshop on aquatic biomonitoring techniques. The workshop was attended by personnel from South Carolina universities, natural resource agencies and regulatory agencies with the objective of identifying biological monitoring techniques to assess the environmental quality of surface waters.

- The Joint Research Centre of the Commission of the European Communities requested each organization that participated in the realtime modeling portion of ETEX (including ETG) to perform an "a priori model evaluation". After reviewing the locations of the specified stations, ETG scientists selected the predictions for the October 23, 1994 ETEX release as the basis for the uncertainty estimate. The predictions for this event were reviewed and subjective uncertainty ranges were estimated at the ten locations for the two parameters.

- Site selection criteria was received from ANL after which a search for a site monitoring well from which to conduct the MAG*SEP demonstration was performed. The only monitoring well located at SRS meeting all the criteria is well DCB-4A (located at the D-Area Coal Pile Runoff Basin). The Treatability Study Workplan for the MAG*SEP was submitted to EPA and SCDHEC on April 26. Ongoing activities of significance include the continued construction of the barrier wall by BMC.Corporation. Projected completion is mid to late June.

- A new Technical Task Plan expanding the scope of the project developed and sent to OTD-HQ. The project will be expanded from an evaluation of algae embedded in foam for bioremoval of heavy metals to an evaluation of the Frisby foam as an immobilization medium for a variety of biomass types (including bacteria and fungi) for use in remediating a variety of pollutants including TCE, PCE, BTEX, and radionuclides in addition to heavy metals.

- A regional groundwater flow model of the Savannah River Site and its surrounding area has been completed.

- A draft scope of work was prepared for the Resonant Sonic subcontract to do vibratory cone penetrometer testing in the M-Area. A draft scope of work was also prepared for a sub-contract with Aprotek, the supplier of the Oleofilter. This is a coalescing filter incorporating an amine coated hydrophilic granular media claimed to adsorb emulsified hydrocarbons.

- Groundwater travel times, source attenuation factors and dose factors for postulated contaminant transport from each $\mathrm{H}$-area waste tank to surface water have been computed.

- A detailed, three-dimensional contaminant transport model of the Old Burial Ground has been developed. 


\section{WASTE MANAGEMENT}

- IWT has completed an initial groundwater interaction study, which indicates that tritium and U-238 have the potential to exceed the performance objectives for the E Area Vaults during the time of compliance.

- Solid Waste Management has recently issued a Soil Management Plan and a new WAC allowing an SRTC recommended method for soil disposal. This will impact disposal of an estimated 12,000 cubic feet of soil per year. Anticipated savings are $\$ 360 \mathrm{~K} / \mathrm{yr}$.

- Results from recent OCTF tests suggest that the HEPA prefilter life will be much shorter than practical(possibly as short as 1-3 days).

- Initial testing of the CIF Kiln Seal Test Unit established baseline air influx rates through the seal in static and rotating modes.

- Preparation of a sample of Tank $51 \mathrm{H}$ sludge for use in the Shielded Cells integrated demonstration of DWPF Batch 1 was completed.

- Recently measured radiolytic generation rates for hydrogen and benzene in simulated In-Tank Precipitation slurries are less than those used in the safety bases calculations.

- A report discussed within describes the potential explosive compounds for the High Level Waste System. Of the 14 classes of compounds discussed, only organics--such as those contained in the Defense Waste Processing Facility recycle stream--require further study. A highlight also addresses progress on that investigation.

- IWT is supporting an ESP-Start-Up Team program to replace the slurry pumps in Tank 51, which are leaking excessive bearing water. Recent accomplishments include modifying the first pump and installing it into the TNX test stand. Plans are to begin the first pump run-in test on 5/8.

- WSRC and the Westinghouse Hanford Company (WHC) are developing an advanced slurry pump as part of the WSRC/WHC Pump Development Program. Design contracts were awarded by WHC to the Westinghouse Electro-Mechanical Division and Lawrence Pumps, Inc.

- The OCTF completed two HEPA filter life tests with $10 \mathrm{wt} \%$ salt in the quench tank, no salt in the scrubber tank, and no particulate injection into the burner. Preliminary test results show that the HEPA prefilters are plugging much sooner ( 2 days) than anticipated ( 30 days). The path forward is to complete the six remaining test runs by late June.

- IWT provided support for the development of a Site Treatment Plan (STP) for mixed waste streams to comply with the Federal Facility Compliance Act (FFCAct) of 1992. A proposed STP (PSTP) was signed by the President of WSRC on $3 / 20$. This was a major milestone towards obtaining SCDHEC approval of the STP and compliance with the FFCAct by 10/95. The path forward is to continue working with 
the STP Task Team (as needed) to ensure the PSTP is approved by the SCDHEC.

- EES provided HLWE with a small-diameter, water-resistant camera and light for inspecting spray rings inside the Evaporator pot.

- EES is continuing the Analytical Cell Upgrades for DWPF.

- EES is continuing development for the Benzene and Nitrite Analyzer Systems for Late Wash. Fabrication of the operator interface control station is $75 \%$ complete, and glovebox modifications will be done in 717-A.

\section{GENERAL}

- The FY97 Five-Year Plan (FYP) has been developed by WSRC for DOE. SRTC has provided programmatic and budgetary input to the Plan. During this month the publication plans for the FYP have changed significantly per agreement between WSRC and DOE-SR management. In an attempt to reduce publication costs, only the Executive Summary volume will be published.

- SRTC has prepared a total of 30 Baseline Change Control Packages during FY-95 and 26 of the packages have been approved by DOE.

- A 3-D conduction analysis of the melter riser agrees qualitatively with temperature measurements. Further model enhancements will be made to achieve better quantitative agreement.

- Development of a dynamic model of the melter pour spout was begun to help identify those operating parameters which could cause or affect oscillations in the pressure control system and subsequently, the glass pouring rate. Simple physical models are being developed to represent separate parts of the system. Initial standalone results show reasonable agreement with the qualitative behavior of the melter pour spout.

- A linear relationship between the common logarithm of the normalized Product Consistency Test boron release and the free energy of hydration, DGp, of glasses within the Purex range of compositions was determined. An upper tolerance limit for this relationship was used to determine the minimum value of DGp which will yield acceptable durability. Purex compositions to be processed in DWPF must be such that their DGp exceeds this value.

- The Experimental Thermal Fluids Group will build a pilot plant in the Thermal Fluids Laboratory (TFL) to test an electrochemical technology for decomposing nitrates and nitrites found in radioactive waste into the form of gases. Actual testing will be with non-radioactive simulants. 
- P\&TG began an aggressive approach on a task from the customer to perform preliminary analysis and documentation addressing the continued capability of the RD rail cask fleet to meet the $19 \mathrm{Q}$ on-site shipping requirements. The task will define what needs to be done to permit continued use of the casks beyond the expiration date of the current certification $(10 / 1 / 98)$.

- A SRTC Technical Area Operational Safety Requirement (OSR) revision package has been approved by WSRC and submitted to DOESR for approval on 5/31/95.

- Revision 1 of the draft SRTC BIO has been completed for WSRC review.

- EES delivered all components for construction of an air-driven vacuum system to $105-\mathrm{K}$ as part of the Disassembly Vacuum System.

- EES, Separations, and Construction personnel successfully removed the elbow section of the FB-Line ventilation duct on May 21 using the elbow removal pipe crawler system.

- EES delivered three prototype units of the second-generation Jaundimeter, an EES invention which uses optical technology to detect and diagnose neonatal jaundice. 


\section{Progress and Accomplishments}

\section{TRITIUM}

\section{Burst Disk Test Support -} D. L. Fish

A summary of the SRS capabilities and costs for support of accelerated tritium aging tests of burst disks for the National Labs was presented in April to the W76 Acorn Process Realization Team (PRT). A rough cost estimate of \$2530K (generated jointly by SRTC and Tritium RTF personnel) was given which would include procedure preparations, reviews, charging container and associated heater costs, design/building of fixtures for conducting the burst tests, etc. RTF personnel indicated that loading could be done on any available loading line but would probably be accomplished on the mini-manifold if available at the time needed. The schedule relayed to the PRT supported an August availability to initiate any work. It was also relayed that one to $11 / 2$ months advance notice will be necessary to enable accelerated loading tests to begin. This is a relatively short time period which benefits from the preparation work which Mike Morgan (SRTC/ASET) is conducting in support of accelerated aging of metal coupons.

Recent discussions with LANL and SNL/CA representatives indicate that some SRS involvement with the accelerated aging tests of burst disks will be likely. Copies of the reduced size charging container (to limit total weight to $<50$ pounds) which SRS is ordering in support of other charging tests were transmitted to the PRT burst disk task team. Mike Hardwick (SNL/CA) is ordering identical units and is designing the disk assemblies/spacers to go in these units. These assembled charging units (with disks already loaded) will be shipped to LANL or SRS for tritium loading, storage and eventual burst testing.
SP-981A Accelerated Shelf Storage -

C. S. Kestin, H. D. Brown K. A. Dunn, M. W. Daniel, C. C. Wilkins, D. E. Moseley, S. M. Wood and S. B. Rhodes

During the Tool Made Sample (TMS) qualification runs for the SP-981A reservoir, metallurgical evaluations of the pinch welds revealed an anomalous bond. It was determined that the unusual bond was the result of poor internal stem conditions in the form of carbon deposits and rough machining marks. The stem condition is thought to be the result of the gun drilling process during fabrication of the reservoir at the Rocky Flats Plant.

As a result of this finding, SNL/CA has requested the SRTC to place six SP-981A reservoirs in the Life Storage Program at $125^{\circ} \mathrm{C}$ for fourteen days. Such an elevated temperature was necessary to accelerate the tritium permeation through the wall of the fill stem in a short period of time. All work will be in compliance with the approved Task Technical Plan, WSRC-RP-95-337.

Ion Current Measurements (ICMs) were made on the secondaries on four different occasions. Results showed that the tritium permeation through the walls of the reservoir and the fill stem had been accelerated.

The first reservoir, SP-981A 19458A was unloaded, with the pinch weld and associated stem being preserved for examination. The pinch weld was metallographically prepared in the longitudinal direction. The bond was characterized as a discontinuous interface having some contaminants. It did exhibit some features of the anomalous bond, but not to the extent shown in the pinch welds during the RTF TMS. 
Pending disposition of these results by SNL/CA, no further reservoirs from this study will be unloaded or examined.

\section{L LF-7 Weld Evaluations -}

C. S. Kestin, C. C. Wilkins, and S. M. Wood

A new LF-7 reservoir has been designed, replacing the 21-6-9 stainless steel material of construction with $304 \mathrm{~L}$ stainless steel. In addition, the new parts will be cleaned with Oakite rather than the acid/nitride process which was used in the past. To fulfill the requirements in the LF-7, Reclamation and Pinch Weld Qualification Plan (Rev. 2) (NMP-TED-940424), the Materials Test Facility was enlisted to perform the weld evaluations.

Section 3.1 of the qualification plan called for eight reclamation test bases to be welded and metallurgically evaluated. All the welds were rated Class II and all the associated measurements were within WR specifications. These results are documented in SRT-HTS-950006.

Section 3.2 of the qualification plan required thirty-two test stems to be pinch welded. Thirty-one of these were evaluated as Class II bonds, which is acceptable. Only one weld was rated Class III, and this weld was made outside the weld parameters. As a result of this failure, four more test stems were pinch welded and metallurgically evaluated. All four bonds were rated Class II.

Section 3.3 specified that eleven PPI reservoirs be reclamation welded. Seven of these were loaded with deuterium and then unloaded. The seven pinch welds were metallographically prepared and rated Class I bonds. The seven reclamation welds were also examined. The bonds were rated Class II, and all the required measurements were acceptable. Three of the four remaining reclaimed PPI reservoirs were burst tested. All three burst at typical pressures and locations. The reclamation welds from these three reservoirs and the remaining reservoir were evaluated. The bonds were rated Class II, and all measurements were within WR specifications. The results of these eleven reclamation weld evaluations are documented in SRT-HTS-95-0096.

The Tritium Facility is currently working on Section 3.4 of the qualification plan which requires reclaiming and filling a number of reservoirs to put in shelf storage at ambient and elevated temperatures.

Terrazzo Reclamation - T. J. Warren, E. A. Franco-Ferreira, C. E. Sweeney, W. R. Kanne, S. A. Hatcher, K. A. Dunn, C. L. Kestin, H. D. Brown and W. J. Rogier

The full scale deuterium-loaded Terrazzo reservoir, which had been successfully reclaimed by laser drilling/laser welding and successfully function tested, was examined metallographically to characterize the laser weld in the fill stem and the cap upset weld made at the base of the fill stem boss. The laser weld showed good form with good mixing of the fill sleeve and tube wall metal and with the desired degree of penetration (about 0.006") into the outer region of the tube wall. Some degree of gas-induced porosity was observed due to the weld being made in a high pressure deuterium atmosphere, but this porosity was not excessive and did not prevent a good sealing weld to be made.

The first of six tritium-exposed fill stems was laser drilled and welded to look for any effects of ${ }^{3} \mathrm{He}$ dissolved in the inner regions of the fill stem wall that could prevent making a good reclamation laser weld in returning tritium reservoirs. Metallographic examination of this drill/weld region showed some signs of ${ }^{3} \mathrm{He}$ induced cracking in the inner two-thirds of the tube wall adjacent to and perpendicular to the laser drilled hole. Further study of this sample is in progress to evaluate these effects and to plan a modified experimental course for the remaining tritium-exposed stems. There is some evidence that the observed cracks formed during the laser drilling operation rather than during the welding step. The next tritium stem might be laser drilled only and then metallographically examined to determine specifically the amount of cracking due to drilling. 
Progress and

These stems had been sealed with high pressure tritium inside a number of years ago as part of another shelf storage program and have seen significantly higher tritium exposures than will the stems in the Terrazzo reservoirs. Any effects seen in these stems will provide a worst case limit relative to any Terrazzo unit exposure. Tritium diffusing into a stem wall creates a $\mathrm{T}_{2}$ profile and also creates a ${ }^{3} \mathrm{He}$ profile in the wall of the fill stem, which has a high concentration on the inner surface and tapers off to essentially zero in the outer radius of the stem wall. Since the reclamation laser weld is only required to penetrate about the outer $.006^{\prime \prime}-.008^{\prime \prime}$ depth of a stem that has a .032 " wall thickness, ${ }^{3} \mathrm{He}$ embrittlement should not effect the laser weld region. However, experimental verification of the ability to make good laser welds in stems that have seen tritium exposure is needed to demonstrate the viability of the reclamation process.

The tritium-containing stems were drilled and cut off in RTF to remove the bulk of the tritium. Only outgassing quantities have to be dealt with during the rest of the handling steps. A high pressure mechanical union was used to connect a fresh fill stem to the contaminated stem. RTF loaded clean deuterium into the stem and pinch welded the new stem, which provided internal pressure for gas outflow during the laser drill part of the test. In MTF the newly loaded stem was sealed in a fixture with a laser window. The outside of the fixture was sufficiently decontaminated to allow laser drilling and welding of the stem sealed in this fixture in the clean laser cubicle. Coordination with HP avoided any transfer of contamination during the processing steps. A gas cylinder was connected to the laser fixture to provide refill gas for the laser weld part of the experiment. The laser welded samples were returned to MTF for removal from the fixture and for destructive examination by metallography to look for ${ }^{3} \mathrm{He}$ effects in the stem wall.

Function Test of the 304-L LF7 Time 0 Reservoirs - W. J. Rogier, T.S. Smail

Changes to the design of the LF7 reservoir have been initiated by Los Alamos. These changes included the change of the material of construction from 21-6-9 to 304-L stainless steel. As part of the qualification of the design changes, 2 new LF7 reservoirs were loaded with deuterium to pressures which were equivalent to time zero (TO) tritium loadings. Both units were then pinch welded and delivered for function testing.

In preparation for the function testing, a new fireset board was assembled by EES. The board was tested with both simulation resistors and a pair of live actuators. These tests allowed us to verify that the power output from the fireset board was sufficient to initiate the test, and also confirmed proper hardware / software compatibility and setup. Other preparations for the function tests included flow tests, receiver changes, jumper tube preparation, instrumentation checks, and procedure development.

Both units were successfully functioned at room temperature on May 2. Deliveries were rapid and complete as expected. Preliminary gas analysis indicates proper deliveries had occurred. Results of the tests will be reported internally as a small stand alone report and externally as part of a larger report covering all related validation activities.

SRTC Participates in the Final JOWOG12 Meeting - J. S. Hölder, D. L. Fish, and W. J. Rogier

The JOWOG-12 is a forum for British and American nuclear weapons scientists and engineers to discuss the chemistry and compatibility of weapons materials. and materials used for processing applications. This meeting has been held periodically since its inception in July, 1959. The $29^{\text {th }}$ and final JOWOG-12 meeting was held May 8 - 11 , 1995, at Allied Signal Aerospace - Kansas City Division. It is anticipated that the forum will continue under a new organization with a new name beginning in June, 1995.

Thirty six (36) papers by twenty two (22) authors were presented during the conference which included a business meeting to discuss the future of JOWOG-12 under the new organization. The papers addressed topics of 
General Compatibility, Boost Systems, Actinide Chemistry, Fire Resistant Technology, Solid State Topics, Internal Atmospheres, and CSA's. U. S. participants hailed from Lawrence Livermoor, Los Alamos, and Oak Ridge National Laboratories, Pantex, Allied Signal, and Savannah River.

SRTC presented four papers under the Boost Systems topic. Their unclassified titles and authors are as follows: "Results of an in-depth study of Acorn cleaning parameters", D. L. Fish and W. J. Rogier; "Flow characteristics analysis of Acorn units by blowdown testing", W. J. Rogier; "Thermodynamics, aging, and tritium processing applications of palladium alloy tritides", J. S. Hölder; and "The Terrazzo reclamation deuterium demonstration", W. J. Rogier and T. J. Warren. See these authors for details on these talks and impressions from the other papers presented at the conference.

The JOWOG-12 business meeting was of general interest, as plans were discussed for the continuation of the forum under a new organization. The JOWOG is being restructured into four main areas: 1) Theoretical Physics, 2) Engineering, 3) Materials, and 4) Facilities \& Infrastructure; each of these main areas will be subdivided. The topics previously covered in JOWOG-12 will now fall into JOWOG-3, which will be broken down as follows: 3A) Nuclear Materials, 3B) NonNuclear Materials, and 3C) Explosives. It was anticipated that SUBWOG's of 3A \& 3B would cover the following topics in parallel: life prediction, aging \& compatibility, fire resistant technology, replacement materials \& processes, waste minimization \& improved processing, and materials characterization. It was generally agreed that the subdivision of JOWOG-3 was not particularly clean or useful, and a motion was carried to propose joint meetings of $3 \mathrm{~A} \&$ $3 \mathrm{~B}$ on a periodic basis. Joint reporting of research in these areas at a JOWOG $3 \mathrm{~A} / 3 \mathrm{~B}$ conference would facilitate discussions among a sufficiently diverse audience to be useful. Tritium topics would fall under JOWOG 3 A.

Materials for Hydrogen-Deuterium Exchange Tests - W. C. Mosley
Four materials have been provided for comparative hydrogen-deuterium exchange tests to determine if any are better than the $\mathrm{Pd} / \mathrm{k}$ presently used in RTF TCAP units. RTF Pd/k from lots 890113,890116 and 890118 that was heated at $1100^{\circ} \mathrm{C}$ and sieved to yield $30-50$ mesh granules is the reference material. Much of the palladium is present as interconnected particles up to $30 \mu \mathrm{m}$ in size in the outer regions of the kieselguhr granules. Low concentrations of palladium particles about $0.5 \mu \mathrm{m}$ in size exist in the interiors of the kieselguhr granules. Further information on this $\mathrm{Pd} / \mathrm{k}$ is given in. WSRC-TR-90-554.

1. RTF Pd/k from lots 890113,890116 and 890118 was sieved to yield $30-50$ mesh granules. This $\mathrm{Pd} / \mathrm{k}$ was not heated at $1100^{\circ} \mathrm{C}$. The palladium is present as particles about $0.5 \mu \mathrm{m}$ in size. Palladium concentrations are much higher in the outer regions of the kieselguhr granules than in the interior regions. Information on this $\mathrm{Pd} / \mathrm{k}$ is given in WSRC-TR-90-24.

2. $\mathrm{Pd} / \mathrm{k}$ batch $\mathrm{RC} 930929$ was made by taking some of RTF Reserve $\mathrm{Pd} / \mathrm{k}$ lot 910923 , heating it at $1100^{\circ} \mathrm{C}$, sieving it to yield $30-50$ mesh particles, and adding additional palladium. This additional palladium was deposited onto the granules by two cycles of soaking in concentrated tetraammine palladium (II) nitrate solution, drying at about $140^{\circ} \mathrm{C}$, and converting the nitrate to metallic palladium by passing the granules through a rotary calciner operated at about $450^{\circ} \mathrm{C}$ in air. This $\mathrm{Pd} / \mathrm{k}$ contains a small amount of palladium oxide that can be reduced to metallic palladium by a single cycle of absorption and desorption of hydrogen.

The palladium in $\mathrm{Pd} / \mathrm{k}$ batch $\mathrm{RC} 930929$ is distributed both as interconnected particles up to $30 \mu \mathrm{m}$ in size in the outer regions of the kieselguhr granules and as particles about $0.5 \mu \mathrm{m}$ in size in the interior regions. The concentration of palladium in the interior regions is higher than that of the two forms of RTF $\mathrm{Pd} / \mathrm{k}$ described above. $\mathrm{Pd} / \mathrm{k}$ batch 
Progress and

RC930929 has a tap density of $0.845 \mathrm{~g} / \mathrm{cc}$ and a palladium content of $45.6 \%$

3. $\mathrm{Pd} / \mathrm{k}$ batch $\mathrm{RC} 931011 \mathrm{~A}$ consists of $38.9 \%$ palladium deposited uniformly throughout 20-30 mesh granules of Chromosorb A(NAW) as particles about $0.5 \mu \mathrm{m}$ in size. Chromosorb $\mathrm{A}(\mathrm{NAW})$ is a more durable form of kieselguhr than the Chromosorb $\mathrm{P}(\mathrm{AW})$ used to make the RTF $\mathrm{Pd} / \mathrm{k}$ and the $\mathrm{RTF}$ Reserve $\mathrm{Pd} / \mathrm{k}$. The 20-30 mesh granules are a standard form for Chromosorb A(NAW) whereas 30-40 mesh granular Chromosorb $\mathrm{P}(\mathrm{AW})$ was a special form that complicated procurement. Palladium was deposited onto the 20-30 mesh granules of Chromosorb A(NAW) by seven cycles of soaking in concentrated tetraammine palladium (II) nitrate solution, drying at about $140^{\circ} \mathrm{C}$, and converting the nitrate to metallic palladium by passing the granules through a rotary calciner operated at about $450^{\circ} \mathrm{C}$ in air. This $\mathrm{Pd} / \mathrm{k}$ contains a small amount of palladium oxide that can be reduced to metallic palladium by a single cycle of absorption and desorption of hydrogen. $\mathrm{Pd} / \mathrm{k}$ batch RC931011A has a tap density of $0.959 \mathrm{~g} / \mathrm{cc}$.

4. Palladium deposited onto $30-40$ mesh granules of porous, sintered aluminum oxide $(\mathrm{Pd} / \mathrm{SA})$ was prepared by the same method as used to prepare $\mathrm{Pd} / \mathrm{k}$ batch RC931011A. The porous, sintered aluminum oxide was purchased as Chemical Process Product SA5421 from the Norton Company. Granules of SA5421 consist of particles of aluminum oxide up to several hundred micrometers in size sintered together with the aid of silicon dioxide to form an aluminum silicon oxide phase at the particle interfaces. Pores up to about $100 \mu \mathrm{m}$ across are present within the SA5421 granules. The phases in SA5421 were identified as corundum (alpha aluminum oxide, PDF 10-173) and mullite (aluminum silicate, PDF 15$766)$ by $x$-ray diffractometry. No chlorine was detected in SA5421 by californium-252 neutron activation analysis (detection limit about 50ppm). The tap density of 30-40 mesh granules of SA.5421 was measured at $1.47 \mathrm{~g} / \mathrm{cc}$.

This $\mathrm{Pd} / \mathrm{SA}$ is designated as batch RC931025. Five cycles of deposition, drying and calcination yielded a product conta.ining $13.35 \%$ palladium and having a tap density of $1.626 \mathrm{~g} / \mathrm{cc}$. Scanning electron microscopy showed that the palladium is present as a layer up to about $20 \mu \mathrm{m}$ thick on the exterior of the granules and on surfaces of pores. Pd/SA batch RC931025 contains a small amount of palladium oxide that can be reduced to metallic palladium by absorption/desorption cycling in hydrogen. Hydrogen absorption/ desorption testing of $\mathrm{Pd} / \mathrm{SA}$ batch RC931025 showed plateau pressures as functions of temperature like those of $\mathrm{Pd} / \mathrm{k}$ but there were also indications of absorption and desorption of hydrogen by the sintered aluminum oxide.

$\mathrm{Pd} / \mathrm{SA}$ having the same palladium density as $\mathrm{Pd} / \mathrm{k}$ with $55 \%$ palladium would have to contain about $35 \%$ palladium. Several grams of $\mathrm{Pd} / \mathrm{SA}$ containing an estimated $32 \%$ palladium were made using twenty-two cycles of deposition, drying and nitrate decomposition. This concentration of palladium on SA5421 seems to be near the maximum possible loading since the pores in this $\mathrm{Pd} / \mathrm{SA}$ were completely filled with palladium.

\section{Defense Board Visit And Response}

K. A. Dunn, M. J. Morgan

Members from the Defense Nuclear Facilities Safety Board (DNFSB) staff visited the Tritium Facility on March 13 and 14, 1995. Technical presentations outlining Life Storage Program history and materials issues were made by SRTC personnel. Tritium Facility personnel presented information regarding the Reservoir Age Management Program (RAMP).

A memo written by Michael Merritt of the DNFSB was received at SRS for a response. This subject of this memo was the "SRS 
Review of Tritium Reservoir Storage and Handling, March 13-15, 1995". The DNFSB cited various observations from the SRS Review. Observations relating to the SRTC technical presentations centered around the validation of the finite difference program, DIFF, used to calculate tritium, hydrogen, deuterium, and helium profiles in materials. A response outlining how the DIFF program has been benchmarked using known equations for diffusivity and solubility and comparing the calculations with measurements made in the laboratory, SRT-HTS-95-0111, was provided to Tritium for inclusion in the overall response to the DNFSB.

Transfer Of IBM Databases To Mac Format - K. A. Dunn, C. S. Kestin

Data gathered for the Life Storage Program has traditionally been input into a classified IBM using either DBASE III or Lotus 123. This system has been cumbersome and not user friendly. In order to make data entry for the Life Storage Program more user friendly the MTF has converted a conventional Mac II to a classified system. All of the classified databases for the Life Storage Program, including MTF Reco and all permeation data, have been transferred from an IBM format to the Mac format. MTF is in the process of converting all of the files to a Microsoft Excel format. This will allow for a more user friendly interface with the computer.

\section{Failure Analysis of Earthquake Valve -} C. S. Kestin, J. R. Wermer, E. A. Clark, S. M. Wood

On March 14, 1995, earthquake valve M2-191E was determined to be leaking across the seat. The suspect valve was transferred to the MTF where the failure analysis is ongoing.

To date, the valve has been leak-tested and confirmed to have a gross leak. When the polymer valve seat and bellows assembly was replaced, the valve was able to hold pressure. A more accurate method of leak-testing will be performed to obtain a precise rate.
Upon disassembly of the valve, it was discovered that the polymer seat material was not the expected color of material. Once the component reaches an acceptable outgassing limit, the seat material will be examined for degradation. Also, a sample of the material will be sent to the Analytical Development Section for identification of the polymer.

Tritium Facilities Waste Characterization Plan - R.A. Malstrom, T.L. Ivey, W.T. Boyce, D. DiPrete, S.F. Peterson

A waste characterization plan must be approved before any waste is sent to the E-area vaults. This characterization plan covers all waste streams generated in a building, and for the Tritium Facilities each building is considered separately. ADS has worked with the Generator Certification Official for the Tritium Facilities, Craig Johnson, on the development of this plan. A critical waste stream is the spent melt crucibles which are used in the extraction of tritium from the irradiated target assemblies. After two or three extractions the crucible is full of spent melt and must be sent to the E-area vaults.

The crucibles are extremely "hot" due to $\mathrm{Zn}-65$ and Cs-135 in addition, to the residual tritium present. In order to collect samples, a robot was fabricated by the Equipment Engineering Section. The samples were dissolved and sent to ADS for liquid scintillation, gamma scan, and ICP-MS analyses. The results of these analyses will be used to certify the crucibles as being acceptable to send to the E-area vaults.

\section{HIVES Thermal Analvsis -}

\section{G. J. Hutchens, J. W. Jerrell}

An analysis has been performed to determine the maximum steady-state surface temperature for a hypothetical tritium reservoir or Hydride Storage Vessel (HSV) stored in the proposed Highly Invulnerable Encased Safe (HIVES). The analysis used mass, momentum, and energy balances to derive expressions for the volumetric flow rate and axial temperature. 
An analysis has been performed to determine the maximum steady-state surface temperature of a hypothetical tritium reservoir or Hydride Storage Vessel (HSV) stored in the proposed Highly Invulnerable Encased Safes (HIVES). The HIVES is a hardened Class 5 steel safe which has been modified for storage of Special Nuclear Material. The HIVES is designed to provide free convection cooling of components stored within.

The analysis of the HIVES was performed using mass, momentum, and energy balances to derive expressions for the volumetric flow rate and axial temperature. A set of calculations was performed for varying HIVES reservoir loading patterns: (1) axially uniform; (2) axially linear, peaked at the top; (3) axially linear, peaked at the bottom. This analysis was also used for HSV storage with axially uniform loading. The analysis was identical except for different loss coefficients for HSV's instead of drawers.

\section{Nuclear Material Field Surveys -}

\section{R. A. Malstrom, F. S. Moore}

ADS surveyed a hot water heater and determined it could be sent to salvage and a cask car for easier decontamination. The steam heated water heater, which had been used for about 30 years to heat domestic water for showers, had been earlier excessed and then returned as contaminated $(10000 \mathrm{dpm})$. A gamma spectrum of the "contamination" showed that it was natural, daughter products of the $U$ and Th series. Over a period of $30+$ years, $U$ and $T h$ from the well water feed collected on the rust deposits in the inlet pipe. This gave a measurable count rate which was detected by HP personnel in the salvage yard. Since the contamination was from natural sources, the water heater could be returned to salvage.

In addition, ADS surveyed a contaminated cask car in the Tritium Facilities so it could more easily be decontaminated. Contamination levels were very high causing problems with dead time corrections in the multichannel analyzer. The major isotopes proved to be Cs-137 and 134, and $\mathrm{Zn}-65$.
Status of Demonstration Tests of $\mathrm{Ca} 0.2$ M0.8 $\mathrm{Ni}_{5} \mathrm{D}_{3}$ for Use as a Compressor W. N. Posey, D. L. Fish, T. J. Warren, W. C. Moseley, E. F. Dyer

Tests completed on a $\mathrm{Ca} 0.2 \mathrm{M} 0.8 \mathrm{Ni} 5 \mathrm{D} 3$ compressor bed in a high pressure cell of Building 774-A showed that sufficient pressure can be generated at $\leq 140^{\circ} \mathrm{C}$ for loading reservoirs in a loading line of the RTF.

The hydride bed and calibrated receiver volume was designed to simulate the gas volume required to load typical reservoirs.

The bed contained $\mathrm{Ca}_{0.2} \mathrm{M}_{0.8} \mathrm{Ni} 5 \mathrm{D}_{3}$, and was activated after being held at vacuum pressure for 24 hours at $135^{\circ} \mathrm{C}$. Bed activation with $\mathrm{D}_{2}$ was begun with the bed at $100^{\circ} \mathrm{C}$, then slowly cooled to room temperature, and then cooled with dry ice to $-65^{\circ} \mathrm{C}$. Activation was completed with 300 psia $\mathrm{D}_{2}$ at a bed temperature of $-65^{\circ} \mathrm{C}$. Final activation with $\mathrm{D}_{2}$ at 300 psia was used to simulate loading a second stage compressor bed from a first stage compressor bed pressurized to $300 \mathrm{psia}$. After all absorption/desorption tests were completed, complete desorption of the bed at $\leq 140^{\circ} \mathrm{C}$ into two larger calibrated volumes showed that slightly more then 75 liters of $D_{2}$ was absorbed by the $\mathrm{Ca} 0.2 \mathrm{M}_{0.8} \mathrm{Ni}_{5} . \mathrm{M}$ is the usual designation for the Misch Metal (reduced from a natural occurring ore), which contains $49 \% \mathrm{Ce}$ $33 \% \mathrm{La}, 13 \% \mathrm{Nd}, 4 \% \mathrm{Pr}$, and $1 \% \mathrm{Fe}$. The calculated $\mathrm{H} / \mathrm{M}$ ratio obtained at activation condition used is 1.16.

The data obtained during 4 absorption/ desorption cycles were in excellent agreement, and the data of 2 cycles is shown in the chart below. Reproducible pressures of 5400 psia were obtained at $\leq 140^{\circ} \mathrm{C}$. No temperature exceeding $140^{\circ} \mathrm{C}$ was tested because: 1 . sufficient pressure was obtained at $\leq 140^{\circ} \mathrm{C}$ and 2. an earlier test by W. C. Mosley of CHTS showed disproportionation of the Ca0.2 M0.8 Ni $5 \mathrm{D} 3$ after a single $150^{\circ} \mathrm{C}$ test. Temperature vs. pressure reproducibility was adversely affected in Mosley's test after the test at $150^{\circ} \mathrm{C}$. No additional tests are currently planned on this material. 


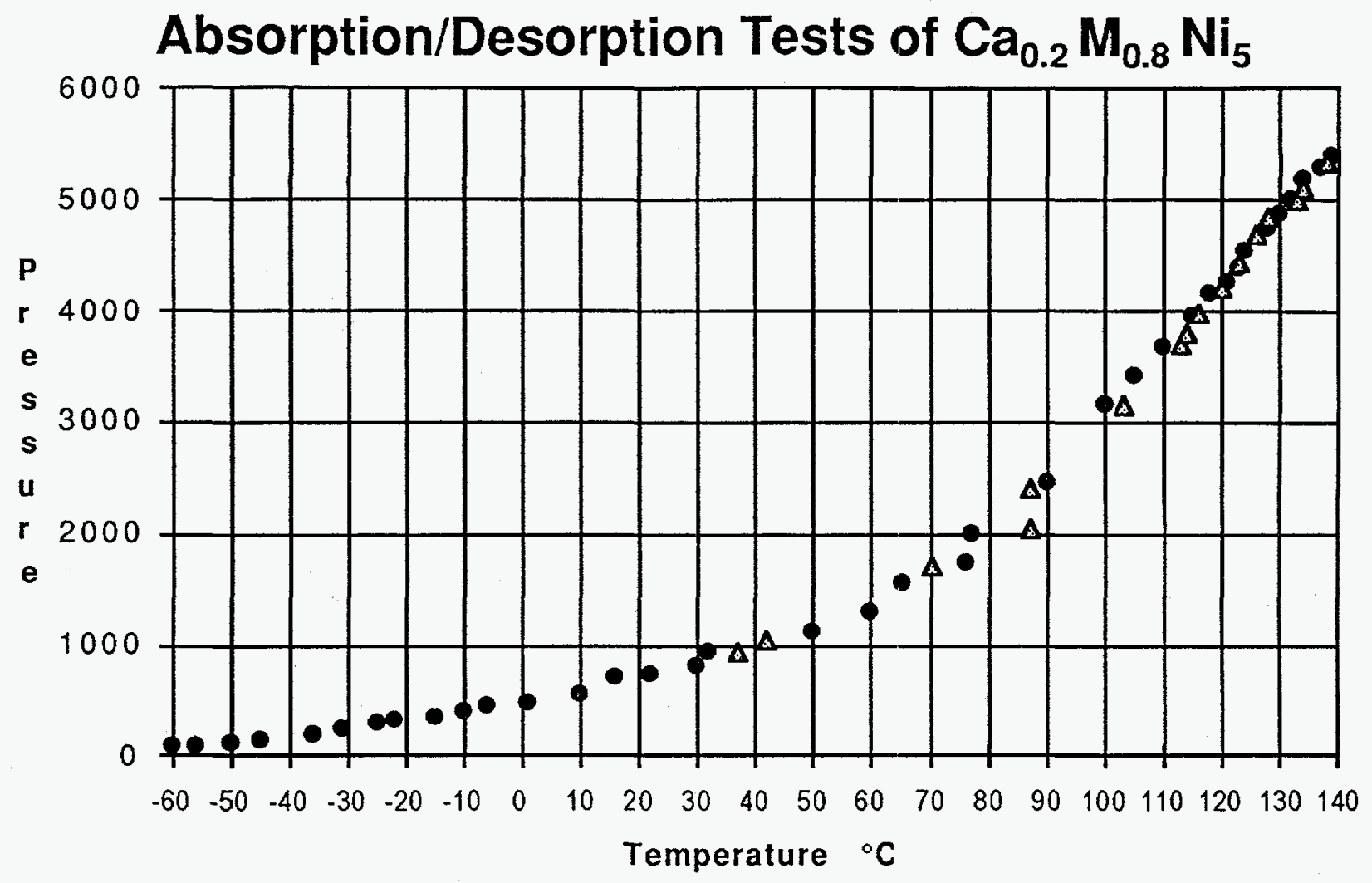

Absorption/Desorption Tests of $\mathrm{CaO} .2$

$\Delta$ Desorption Test on 4/28/95 (3rd) M0.8 Ni5 D3 on 5/1/95 (4th)

\section{Records Identification At Mound -}

\section{K. A. Dunn}

Personnel from SRS visited Mound April 13, 1995 , to conduct a records review for A, C, and $T$ vaults. The purpose of the review was to identify records to be transferred to SRS in support of the RSO and GTS mission. These records are located in areas which have been shown to be contaminated or have the potential to be contaminated.

A printout identifying boxes full of records for $\mathrm{C}$ and $\mathrm{T}$ vaults was provided to SRS by Mound personnel. The boxes which SRS personnel identified as potential candidates for shipping were pulled. from $\mathrm{C}$ vault and reviewed for content. No documents from $\mathrm{C}$ vault were identified to be shipped. The $\mathrm{T}$ vault was not available for review by SRS personnel.

A card filing system is used at Mound in the A vault. SRS personnel reviewed the document titles on the cards dating from 1989-1995 for applicability to the RSO and GTS mission being transferred from Mound to SRS. Approximately 430 documents were identified as potential candidates for transfer. These documents will be pulled and SRS personnel will review each one for content and will then evaluate how to transfer the required documents. 
Progress and

\section{QUADSTAR Transfer from Mound to} SRS - G. L. Gill

A trip to the Mound (OH) complex was made to meet with the current end-user and programmer of the QUADSTAR database. QUADSTAR is the vehicle used to record surveillance test results and issue a report to the weapons design agencies. The database is an "in-house" code developed by Mound personnel. QUADSTAR has been transferred to SRS and will continue to be used. The trip was intended to provide an introduction to the database, its input requirements (type of input and sources of the information), and meet with the current users. These objectives were met.

\section{Tritium Support - Joe Cordaro}

EES completed all as-built record and development drawings for Project 4173 (over 110 drawings total) covering the design of the following: the High Speed Data Acquisition System (DAS), high frequency fireset board, constant current fireset board, stripper control chassis, automatic valve control chassis, grab sample manifold, internal bell jar piping, three laser unloading fixtures, stripper beds, Z-bed recovery stripper adapter plates, vacuum ion chamber, and oxygen/moisture instrument assembly. EES authored and performed over 15 calibration and checkout procedures and assisted with numerous start-up problems. All project budget and schedule milestones were met.

The existing DAS for the pneumatic burst facility is obsolete and could not be repaired after a recent hardware failure. EES, using a multichannel strip chart recorder and a peak detection voltmeter, installed a temporary DAS capability. The permanent DAS hardware was ordered and has been received. Hardware integration is in progress.

EES repaired one of the Tritium Facility calorimeters, dramatically improving the sample measurement time. Measurements that previously took over 20 hours, have been reduced to 4 hour baselines with sample measurements taking from 5 to 6 hours.

\section{Non-Nuclear Reconfiguration Joe Cordaro}

EES is responsible for the design and fabrication of three Kanne skids which will be used in conjunction with the new Environmental Chambers. The skid design includes a Kanne chamber, rotameter, miscellaneous piping, valves, blowers, filters and fittings. The skids are being fabricated and should be completed during the first week of June. The Kanne skids will be installed in the room with the new Environmental Chambers. The Kanne skids will monitor for tritium and alert personnel of any increase in activity.

EES completed a successful burst test of a $3 \mathrm{~J}$ reservoir. The fully integrated test verified correct operation of all major components. The test was run in conjunction with Tritium Operations. EES turned over the system on May 24, 1995 with only a few B punch list items remaining. EES was requested to shorten the original schedule by 6 months and successfully met the expedited schedule. EES will continue to assist Tritium Operations with training of personnel as well as with B punch list items over the next month. 


\section{SEPARATIONS}

\section{Separations Support_-Jim Wong}

EES and Separations held an initial program review for the FB Line Bagless Transfer program to introduce the EES design team, consisting of eleven engineers, designers, and technicians. Job responsibilities, purchase requisition status, schedules, and the path forward were discussed.

EES gave four demonstrations of the prototype Bagless Transfer unit at the request of Rocky Flats, Oak Ridge, LANL, and LLNL.

EES and Separations held an SNM Storage Vault program review to introduce the team and discuss project status, job responsibilities, and FY95 goals. EES currently has ten engineers and scientists assigned to this task. An EES engineer recently attended the ID Expo (bar code convention) in Chicago to research the possibility of using 2-dimensional bar codes on the Storage Facility Containment Vessel. A vast amount of information was obtained that will be useful on the SNM Storage Vault program.

EES was requested by Separations Engineering to design and fabricate a custom vacuum filter housing to replace the current housings in HBLine. The existing vacuum filters (polypropylene) are failing at an unacceptable rate. EES provided a conceptual design, cost estimate, and schedule to Separations Engineering for approval. Separations Engineering had a great deal of input in the development of the concepts. The conceptual design uses the new 304 stainless filters proposed for use in phase III of HB-Line. EES is currently testing these filters for acceptability and will continue this effort for the new vacuum housing.

Dissolution of Plastic Bags for SS\&C Processing - R. A. Pierce and J. D. Clark

An alternate flowsheet is being studied which will permit the processing of sand, slag, and crucible (SS\&C) in F-Canyon instead of FBLine. As part of the flowsheet development, studies are being conducted with acid-soluble plastic bag materials which might replace insoluble PVC and polyethylene.

Flowsheet verification studies began this week using nylon as the soluble bag material. These tests will simulate F-Canyon dissolution, valence adjustment, and solvent extraction to determine the impact of dissolved bag compounds on F-Canyon processing. Dissolution is being conducted in $4.5 \mathrm{M}$ $\mathrm{HNO}_{3}$ for 24 hours at $90-95^{\circ} \mathrm{C}$. Salts containing fluoride, aluminum, iron, and calcium will also be added in specified amounts to simulate their presence as a result of SS\&C dissolution.

Once dissolution is complete, the resulting solution will undergo separate valence adjustments with ferrous sulfamate and sodium nitrite. Last, we will simulate the operation of both F-Canyon solvent extraction banks. Processes downstream of solvent extraction will not be tested at this time because it is believed that the impact of acid soluble bags will appear in one of F-Canyon operations being tested, not in subsequent FB-Line operations.

Plutonium Ceramic - D. G. Karraker, W. G. Ramsey and J. Middleton

A process for dissolving powdered materials in the F-Canyon could lead to canyon processing of powdered Pu-bearing residues, such as RFP incinerator ash and JB-Line glove box sweepings. However, nuclear safety considerations restrict charging powdered materials to a sub-critical mass. When the material is in a homogenous matrix, the dissolver charge will be controlled by the final $\mathrm{Pu}$ concentration of the dissolver solution, about a factor of ten larger charge.

This study aims to find an oxide that will dissolve $\mathrm{PuO}_{2}$ and incorporate the $\mathrm{Pu}$ into a matrix that will dissolve at the same rate as the $\mathrm{Pu}$. Rather than simulate residues, the reaction between $\mathrm{PuO}_{2}$ and an acidic oxide is under investigation, since a reaction between $\mathrm{PuO}_{2}$ and the matrix material is essential to a homogenous material for dissolving. 
$\mathrm{PuO}_{2}$ was fired at $1100^{\circ} \mathrm{C}$ with $\mathrm{B}_{2} \mathrm{O}_{3}$ in $\mathrm{PuO}_{2}: \mathrm{B}_{2} \mathrm{O}_{3}$ mole ratios of $1: 1,1: 2$ and $1: 3$. The product was a hard glass that dissolved in $\mathrm{HNO}_{3}$ leaving a $\mathrm{PuO}_{2}$ residue. X-ray diffraction patterns of the powdered glass showed that $\mathrm{PuO}_{2}$ had not reacted with the $\mathrm{B}_{2} \mathrm{O}_{3}$. Ternary boron oxides and phosphate glasses will be prepared next.

$\mathrm{PuO}_{2}$ was then fired at $1100^{\circ} \mathrm{C}$ with $\mathrm{FePO}_{4}$ frit at $14 \mathrm{wt} . \%$ and $25 \mathrm{wt} \% \mathrm{PuO}_{2}$ loadings to form a solid glass. The x-ray diffraction pattern for the $14 \mathrm{wt} . \%$ glass showed only amorphous material; no $\mathrm{PuO}_{2}$ was found in the pattern, indicating that $\mathrm{PuO}_{2}$ had reacted with the frit. The 25 wt. \% glass was mainly amorphous, with weak $\mathrm{PuO}_{2}$ and $\mathrm{PuP}_{2} \mathrm{O}_{7}$ lines in the pattern. These phases are estimated to be less than $5 \mathrm{wt} . \%$ of the total $\mathrm{Pu}$. Further studies include ternary oxide frits and dissolving tests on the $\mathrm{FePO} 4-\mathrm{Pu}$ glass.

\section{Characterization of Tank 9.6 Solids}

\section{J. H. Gray, K. J. Kalbaugh}

The characterization of solids collected from the last two batches from Tank 9.6 confirmed both volume and plutonium content have continued to decrease. Results obtained from 772-F (A. C. Hatfield) and SRTC labs found the volume of solids decreased from highs of 0.3 to 0.4 milliliters to amounts as low as a few hundredths, hardly visible milliliters. The corresponding plutonium content had decreased from hundreds of grams in tank solids to 10-20 grams.

These low values calculated for plutonium content in tank volume solids have shifted emphasis from criticality issues to determination of type of plutonium compounds involved and to an explanation for the unexpected increase in volume followed by the subsequent decreases.

Some of the most useful information was obtained from Inductively Coupled Plasma (ICP) solution analysis of dissolved solids. When volume and plutonium content were high, more than sufficient phosphorus was present to account for all plutonium in the form of Pu-P compounds. After volume and plutonium content decreased to low levels, no phosphorus was detected in solids and the abundance of elements shifted from iron and silicon dominated to silicon, sodium, and aluminum dominated. Without phosphorus, plutonium oxide has been the compound typically found in solids in most canyon vessels.

An explanation suggested by D. F. Chostner (Sep. Eng.) for the presence of $\mathrm{Pu}-\mathrm{P}$ compounds was the release of Pu-DBP (dibutyl phosphate) solids from Tank 9.6 walls. Another possible source of the phosphorus is DBP in diluent wash used to remove tributyl phosphate (TBP) from the 2BP second plutonium cycle product solution before transfer to Tank 9.6. Since the current diluent wash inventory has been in use for five or more years, sufficient radiolysis/hydrolysis of TBP may have taken place to produce DBP. A sample of the diluent wash has been received for DBP analysis.

Mixing in Canyon Tanks-SolidsSuspension - N. M. Hassan and Y. J. Simpkins

Criticality Engineering Group (NMPD) has been performing nuclear criticality safety analyses for $\mathrm{F}$ and $\mathrm{H}$ canyon tanks. Typical analyses quantify the maximum safe solids mass in the tanks by assuming that the installed paddle agitators are providing sufficient power input to uniformly disperse the fissile solids in bulk solutions and the sampling system presently used is capable of providing representative samples in tanks known to contain fissile solids. However, no documentation is available to justify that the installed agitation/sampling system in the canyon vessels are capable of providing complete and/or homogeneous suspension.

The experimental work and data analyses of the solids-suspension study have been completed. The experimental data were obtained for several different variables that are capable of adjustments on the full scale; namely agitator speed, height of total liquid in the tank, and number of agitators. The data were also obtained for those variables that are inherently difficult to characterize in the full scale; namely particle size distribution and 
mean solids concentration (percent weight). The data were provided for axial and radial distributions as functions of total liquid height, agitator speed, and number of agitators and some recurring trends were identified. A technical report summarizing the findings of the experimental work will be issued by Chemical Technology Group (CTG) in the next few weeks. The details of the experimental results along with scale-up correlations for the full scale process tanks will be prepared by CTG along with GA Tech Professor A. H. P. Skelland.

\section{Processing Tank 13.5 Carbonate} Wash Solution - J. H. Gray, K. J. Kalbaugh, D. F. Chostner

One option under consideration for processing plutonium carbonate wash solution in Tank 13.5 is acidification with $\mathrm{HNO}_{3}$ followed by purification of plutonium in the second plutonium cycle. Previous attempts to convert the carbonate wash solution to a feed suitable for the second plutonium cycle required prolonged boiling (50-60 hours) in $12 \mathrm{M}$ $\mathrm{HNO}_{3}$.

Since extensive radiolysis/hydrolysis of the dibutyl phosphate (DBP) may have taken place during the 4+ years of interim storage, a recent sample from Tank 13.5 is being treated to determine if less severe conditions would be required to convert the 13.5 solution to suitable second plutonium cycle feed.

DBP analysis of the 13.5 solution found 2640 ppm DBP. This high DBP value indicates conversion to suitable second plutonium cycle feed will still be difficult.

The first conversion attempt acidified with $12 \mathrm{M} \mathrm{HNO} 3$ followed by heating at $90-95^{\circ} \mathrm{C}$ for four hours. Then an extraction and strip pickup test was performed with solvent from Tank 906. The alpha $\mathrm{dpm} / \mathrm{ml}$ left in the solvent after nine strip stages remained high, at $6.7 \times 10^{6} \mathrm{dpm} / \mathrm{ml}$. Sufficient DBP was present to prevent plutonium stripping from the solvent. Additional treatment conditions are being considered.
Hydrogen Generation in FB-Line Tanks Containing HSA and HAN J. R. Smith, K. J. Kalbaugh, and J. B. Schaade

Alpha particle emitting radioactive materials produce hydrogen, oxygen, and traces of other gases in nitric acid solutions through radiolysis. The production rate of these gases depends on the dose rate from the emitted alpha particles and the nitric acid concentration of the solution. Calculations show radiolysis can potentially cause hydrogen build-up in unvented tanks.

The hydrogen concentration in the off-gas, generated by radiolysis, from a $2.9 \mathrm{M} \mathrm{NO}_{3}$ /0.1M HSA (sulfamic acid) $/ 0.16 \mathrm{M} \mathrm{Pu}+3$ solution was determined earlier to be nearly constant at $2.7 \%$ for more than two weeks. The $2.7 \%$ value is important because the lower flammability limit for hydrogen in air is $4.0 \%$. Addition of $\mathrm{Mn}^{+2}$ to the solution reduced the hydrogen concentration further to a minimum of $1.9 \%$, about a $30 \%$ reduction. Addition of urea, to $0.1 \mathrm{M}$, had little effect. This was because urea competes poorly against sulfamic acid in scavenging nitrite under these conditions (off-gas analysis gave a $\mathrm{CO}_{2}$ value of $0.6 \%$, which corresponds to less than $1 \%$ of the nitrite being scavenged by urea).

\section{Processing Plutonium Residues -}

R. A. Pierce, J. H. Gray, J. D. Clark, K. J. Kalbaugh

Additional studies involving microwave heating of a flyash mixture containing an aluminum fluxing agent, uranium oxide ( $\left.\mathrm{UO}_{2}\right)$, and thorium oxide ( $\left.\mathrm{ThO}_{2}\right)$, have been completed. Whereas previous experiments did not have a strong reductant present, magnesium metal was added as the reductant to the last batch of flyash. The purpose of magnesium was to reduce as much of the $\mathrm{UO}_{2}$ to uranium metal as possible to maximize formation of a soluble uraniumaluminum alloy.

The addition of magnesium did not appear to have improved the solubility characteristics of 
$\mathrm{UO}_{2}$. Initial results indicate most of the uranium already dissolves as long as the aluminum fluxing agent is present in the flyash mixture.

The addition of magnesium did not eliminate or even reduce the quantity of insoluble material (dross) left after dissolution in $\mathrm{HNO}_{3}-\mathrm{HF}$. The compounds in the dross only changed from $\mathrm{Li}-\mathrm{Mg}$-Fe fluoride and $\mathrm{Li}$ Al-O fluoride mixtures to $\mathrm{Mg}$-Al oxide, $\mathrm{Mg}$ nitrate-hydrate, and $\mathrm{Mg}$ fluoride mixtures.

The need for a strong reductant, such as magnesium metal, can only be established using actual plutonium scraps and residues. Additional experiments may involve incinerator ash containing high fired $\mathrm{PuO}_{2}$ and FB-Line floor sweepings containing both oxides and fluorides of plutonium.

\section{Earthquake Induced Fire in Frame} Waste Recovery Column -

E. A. Kyser, J. E. Laurinat, M. E. Hodges and N. M. Askew

The Frame Waste Recovery column is operated as an anion exchange process to recover $\mathrm{Pu} 238$ in $\mathrm{H}$-Canyon. Due to the radiolytic heating of $\mathrm{Pu} 238$ loaded on the resin, this column is especially vulnerable to temperature excursions during flow interruptions. Under normal operating conditions the temperature is monitored and the flow through the column is closely controlled. Flow through the column removes the radiolytic heat from the column and prevents a significant temperature rise from occurring. Technical standards limit the operating temperature of the column to $60^{\circ} \mathrm{C}$ and the period of flow interruptions to 15 min. If flow were to be stopped, the radiolytic heating of the $\mathrm{Pu} 238$ would cause the column temperature to rise. At temperatures in the range of 80 to $100^{\circ} \mathrm{C}$, the heat from the chemical reaction between the resin and nitric acid becomes significant relative to radiolytic heating and rate of temperature rise starts to accelerate significantly. Significant pressure rise does not occur due to the venting of the column. This allows the temperature to rise only up to the boiling point of the nitric acid mixture when mostly water starts to evaporate. As water preferentially evaporates from the solution, the nitric acid concentration increases and the boiling point slowly rises from about $108^{\circ} \mathrm{C}$ to $121^{\circ} \mathrm{C}$. Since the rate of reaction depends on both the temperature and the nitric acid concentration, the reaction will continue to accelerate during this time, but most of the heat produced will be dissipated by the evaporation of water and nitric acid. As long as the liquid layer covering the resin exists, the resin will not ignite. Most of the research work in the literature was performed with drained resin. The accidents that have occurred generally involved inadequately vented (or unvented) systems that overpressurized from the rapid chemical reaction. In an unvented system the temperature will rise uncontrollably, but in a vented system with liquid present the temperature rise is controlled by evaporative cooling until the liquid is consumed.

In the event of a severe earthquake, flow through the column cannot be maintained. CHTS was requested to investigate the length of time after a flow interruption before the resin-nitric acid reaction on a fully loaded $\mathrm{Pu} 238$ column progresses to a fire situation. The point where the reaction is beyond our ability to bring under control is difficult to pin down because of uncertainties in kinetic model assumptions and then the necessity of integrating these uncertainties as the resinnitric acid reaction is in an accelerating condition. A level one confirmed calculation has been performed that conservatively shows that it will take almost 2 hours for an adiabatic section of the loaded column to heat from $50^{\circ} \mathrm{C}$ to $110^{\circ} \mathrm{C}$ (boiling $8 \mathrm{M} \mathrm{HNO}_{3}$ ). Additional confirmed calculations have also shown that the gassing rate from the column at those temperatures can be vented without significant pressure rise. This work contributed to the resolution of the SAR inadequacy that recently curtailed Pu238 processing in H Canyon.

Hydraulic Analysis of FWR Ion Exchange Column Vent (M. E. Hodges and E. A Kyser) 
As part of a study of hypothetical accident scenarios associated with $\mathrm{H}$-Canyon, the adequacy of the frame waste recovery column vent to handle boiling conditions within the column was required.

A detailed hydraulic analysis of the column vent has been completed. The vent is unusual in that it consists of the annular space between the inner wall of the agitator support, a $3^{\prime \prime}$ schedule 40 pipe and the outside of the agitator shaft, 1.25" in diameter. With an assumed boilup rate 495 liters of water vapor per minute at $130^{\circ} \mathrm{C}$, the pressure drop through the column vent was found to be negligible.

\section{Development Work for $\mathrm{F}$ and $\mathrm{H}$ Canyons \\ F. S. Moore}

ADS provided several small, NIST-traceable, $\mathrm{Pu}$ sources to both $\mathrm{F}$ - and $\mathrm{H}$-Canyons for functional tests of the canyon alpha effluent monitors. The canyons are currently required to perform a functional test of each monitor system on a weekly schedule. Although both canyons have been complying with the weekly testing requirement, they have not been able to comply with the additional requirement that the alpha sources be NISTtraceable. By obtaining these sources from ADS, NMSP is able to meet all of their requirements while saving a significant amount of money over the cost of buying similar sources.

Hydrogen Sensor for HB-line - S. E. Nave

WSRC-TR-95-0168, Fiber Optic Raman Hydrogen Sensor For HB-Line (U) was issued describing the specifications and performance of an analyzer developed for online measurement of hydrogen in dissolver off-gas. The analyzer will measure hydrogen in the range $0.1 \%-100 \%$ in the presence of NOx gases.

Previous work to provide a small, very simple sensor for on-line hydrogen measurement is being revisited in light of the continuing progress in SRTC with sol gel technology. A palladium bridge sensor had previously been identified that could measure hydrogen if a membrane could be found to allow hydrogen access to the sensor while screening out other gases. A variety of sol gel coating formulations will be investigated as the possible solution to the need.

\section{Assistance to F-Area Labs - L. C. Baylor}

By request of Ron Livingston of Analytical Laboratories ADS has begun an effort to replace the old HP-8451 spectrophotometer used to service the B-Lines with a newer HP8452A unit and updated software, while maintaining the current operator interface (a TransTerm keyboard). A copy of the old code was obtained and it is being adapted to be used with the SPECTRO software that controls the HP-8452A units.

Hydrogen Generation Rates in the LR56 Cask System - G. J. Hutchens

Among the issues to be addressed in evaluating the LR-56 Cask system for the transport of high-level liquid waste is the rate at which hydrogen gas $\left(\mathrm{H}_{2}\right)$ is liberated from the solution and the time required to reach the lower flammability limit (LFL) of $4 \% \mathrm{H}_{2}$ in the vapor space. Previous work determined the time to reach LFL from the radiolysis of water in $\mathrm{Pu}$ solutions. However, these calculations ignored the effect of nitric acid on the $\mathrm{H}_{2}$ generation rate.

The presence of nitric acid in $\mathrm{Pu}$ solutions suppresses the $\mathrm{H}_{2}$ generation rate due to scavenging reactions between nitrate ions and $\mathrm{H}$ atoms. In other words, the more concentrated the nitric acid in the solution, the less $\mathrm{H}_{2}$ is generated.

Experimental data for $\mathrm{G}\left(\mathrm{H}_{2}\right)$ (number of molecules liberated $/ 100 \mathrm{eV}$ absorbed) for $1 \mathrm{M}$ and 5M Pu-nitric acid solutions were fit to a linear interpolating polynomial of the form $\mathrm{G}=\mathrm{AM}+\mathrm{B}$ where $\mathrm{M}$ is the solution nitric acid molarity. This allowed $\mathrm{G}\left(\mathrm{H}_{2}\right)$ to be determined at nitric acid concentrations between $1 \mathrm{M}$ and $5 \mathrm{M}$. Once the value of $\mathrm{G}\left(\mathrm{H}_{2}\right)$ was known -for the specified acid 
concentrations, the volumetric $\mathrm{H}_{2}$ generation rate and time required to reach LFL were calculated. The time to reach LFL is extended by including nitric acid in the calculations. For the case of the fully loaded cask, the time to reach LFL is extended from 5 hours, neglecting the nitric acid, to 56 hours, when the effect of $2.5 \mathrm{M}$ nitric acid is included.

\section{Recertification Activities - Q1} Questions - T. K. Houghtaling

The 5320 radioactive material packaging is used by several sites within the DOE complex for transport of heat source material over public highways. The authorization basis for use of the packaging, or Safety Analysis Report - Package (SARP) must be reevaluated periodically and approved by $\mathrm{DOE}$ Headquarters. Approval is provided in the form of a Certificate of Compliance (COC) which states that the packaging meet applicable federal and other regulations and specifies transportable payloads.

Development of responses to Q1-series questions from DOE Headquarters continued. The first milestone required half of the questions to be answered by the end of April. Packaging and Transportation (P\&T) delivered a presentation to the customer on $4 / 28 / 95$, describing completion of 83 of 152 questions. The milestone was met even though P\&T lost its nuclear safety resource to the voluntary separation program. Demonstration of the achievement was provided by distribution of the answers at the meeting. A cover letter documenting completion of the milestone was also distributed.

Of significance in the area of package analysis are two features. First, a three-dimensional model of the 5320 is being developed for dynamic analysis of drop testing that the 5320 must survive. Acceleration results from the 3$D$ model will establish a defendable basis for analysis of component stresses. Dynamic drop analysis will also provide stress states within the bolts that fasten the flanges of the secondary containment vessel (SCV). Second, a thermal model of the 5320 has been developed and benchmarked against a 5320 fire test conducted at Sandia National Laboratory. Unlike the fire test, the analytical thermal model can emulate the effect of the radioactive heat-source payload on temperature magnitudes and distribution throughout the package. 5320 survival of the regulatory fire will be shown by analysis and defended by the benchmarking of the model. 


\section{ENVIRONMENTAL}

\section{EG\&G Remote Sensing Acquisition Completed - H.E. Mackey}

The annual spring overflight of SRS by the EG\&G Remote Sensing Laboratory of DOE was flown between April 20 and May 4, 1995. All target areas were successfully completed. Multispectral scanner data were acquired for closure caps in M Area, F- and H-Area seepage basins, the mixed waste management facility and the sanitary landfill; both daytime and predawn thermal scanner data were collected. The Par Pond system was flown at $10 \mathrm{~K} \mathrm{ft}$ and $25 \mathrm{~K} \mathrm{ft}$ above ground level (AGL) to support the CERCLA and NEPA characterizations of that system. The Pen Branch corridor and delta, as well as the SRS swamp were flow to support the Pen Branch reforestation program and the planned River Water System Shutdown assessment. Other targets for data acquisition included: Lost Lake, Tims Branch and Steed Pond, R Reactor, D Area and TNX. False color infrared imagery was acquired for all areas for which daytime MSS data were acquired, and normal color imagery was acquired for all SRS facility areas.

EG\&G implemented two new systems to decrease cost and improve the quality of mission acquisitions. On board GPS eliminated the need for additional personnel to place ranging navigational transmitters on areas fire towers and allowed the flights to be flown along predetermined flightlines defined by UTM coordinates. This system eliminated the need for test flights and reflying of flightlines. Additionally, the high density MSS onboard data tapes were decommed at the Bush Field Airport allowing daily review by the EG\&G and SRTC project scientists. This 'field decomming' of the data should also allow more rapid processing of the data at the Remote Sensing Laboratory in Nevada.

\section{D-Area Powerhouse Privatization -}

\section{J. Stewart}

The Department of Energy is currently conducting contract negotiations with the South Carolina Electric and Gas Company (SCE\&G) for operation of the D-Area powerhouse (484-
D). ETG reviewed air quality impact analyses carried out by Halliburton NUS Corporation on behalf of DOE. Detailed plans and elevations of the 484-D powerhouse area were prepared using site drawings and ground surveys. Using an updated version of the EPA Building Profile Input Program (BPIP), the effective dimensions of the structures were calculated for use in assessing downwash and wake effects on the plumes from the stacks. Modeling of SOx emissions then commenced. Site compliance cases were modeled first and disclosed a theoretical compliance discrepancy if the powerhouse was operated at the full capacity allowed by the air permit. Using data projected by the Power Department, ETG began modeling numerous emissions scenarios to determine what, if any, modifications to powerhouse operations would be required to prevent exceeding the ambient air quality standard if the powerhouse were ever operated at full capacity with the emissions levels allowed by the permit.

\section{M-Area Vendor Treatment Plant Air Quality Modeling - J. Stewart}

Nine emissions scenarios for oxides of nitrogen emissions (NOx) from the projected vitrification plant in M Area were modeled to support a modified air permit application. The scenarios modeled represented cases under three different operating strategies. The estimated maximum site boundary concentrations calculated using the projected emission rates for NOx were found to be very small in relation to the ambient air quality standard.

\section{Pen Branch Reforestation - E.A. Nelson}

Planting of twelve acres of deep water habitat on the Pen Branch delta was performed by SR Forest Service personnel in April. Planting was delayed because of high water in the swamp and concern about the viability of the planting material because of the extended storage period. This completes the major planting program for the reforestation program. Remaining activities include replanting of areas where initial plantings are lost or damaged. Monitoring plots will be established in the Pen Branch delta to monitor the progress of the reforestation in this area. 
Monitoring of stream invertebrates and herpetofauna by SCUREF personnel is continuing to document the reestablishment of other components of the Pen Branch wetland ecosystem. Herpetological studies are being coordinated with SREL to integrate these data into their turtle marking program.

Dose Modeling for 1994 Environmental Report Completed - W. H. Carlton and G. T. Jannik

Dose modeling of the 1994 environmental radioactive releases was completed. The doses were modeled for the maximum, average, and population dose from atmospheric releases. Additional modeling determined the maximum and average population, and water treatment doses from liquid releases. Releases continue their downward trend although the liquid doses were slightly higher because of reduced flow of the Savannah River.

\section{Measurement of Cs-137 in Pollen}

W. G. Winn, C. E. Murphy

A final report (SRTC-ETS-95-260) on the March 23 pollen measurements near $\mathrm{H}$-Area Retention Basin was issued this month, upgrading and refining an earlier preliminary report (SRTC-ETS-95-194). In particular, it was noted that the associated Cs-137 dose from pollen was $2.0 \mathrm{nRem} /$ day, a factor of two lower than reported earlier. Also, the final report includes a plot of pollen levels reported throughout March and a table comparing the airborne doses for other cases of interest. The dose measured on March 23 was well below the ICRP-recommended de minimis of 2700 nRem/day (1 mRem/yr).

Support for L-Area Disassembly Basin Ion Exchange Studies - W. G. Winn

Support was provided to IWT for evaluating a pilot-scale ion-exchanger facility to remove Cs137 from L-Area Disassembly Basin. Low-level gamma spectrometry results were reported in March (SRTC-ETS-95-178), and the support work was completed this month with a report on beta-liquid scintillation results (SRTC-ETS95-258).
Dose Modeling for Offsite Shipment of Low-Level Waste - A. A. Simpkins

Dose-release factors were determined in support of the Waste Management Environmental Impact Statement (EIS) for a hypothetical radioactive release at Barnwell, South Carolina, from a shipment of low-level waste. Both atmospheric and liquid releases were analyzed. Atmospheric dose codes used at SRS do not have the ability to handle offsite releases. Setting the release point at the closest onsite point produces adequate results since the meteorology does not vary significantly for the Barnwell site, which is 5 miles from the boundary. Dose-release factors were modeled for a hypothetical individual $805 \mathrm{~m}$ ( 0.5 miles) from the release point and for the $80 \mathrm{~km} \mathrm{(50}$ mile) population.

Development of a Region a
Groundwater Flow model for the
Savannah River Site and its
Surrounding Area - R. Hiergesell, D.
Jackson, D. Tuck

A regional groundwater flow model of the Savannah River Site and its surrounding area has been completed. The model incorporates new information describing the regional hydrogeologic system in the parts of South Carolina and Georgia immediately surrounding the Savannah River Site. This information was utilized, along with previously available information from both on-site and off-site locations to develop a groundwater flow model of the Savannah River Site. The model code utilized for this investigation is FACT, a finiteelement code having full 3-dimensional capability as well as the ability to simulate contaminant movement.

The model consists of four aquifer units and the three confining units situated between them. Layers elevations are offset where subsurface faults are hypothesized. Model boundary conditions have been selected and long-term pumpage from specific wells has been incorporated. Approximately 85 calibration simulations were conducted. Vertical and horizontal hydraulic conductivity values for each layer were adjusted betwen successive runs and eventually an adequate match of 
simulated hyraulic heads and measured hyraulic heads was achieved. A draft report was prepared documenting the development work completed to date. The report is currently in peer review and incorporation of comments by technical reviewers is in progress. The final report will be issued as a WSRC Technical Report in the near future.

\section{Dosimetry Technical Support -}

\section{A. A. Simpkins, G. T. Jannik, and W.} H. Cariton

Technical dosimetry support this month included:

- Modeling doses using LADTAP XL for E Area hypothetical release

- Modeling doses using AXAIR89Q for hypothetical $R n-220$ release from $H$ Area

- Calculating the hypothetical dose from breathing pollen containing Cs-137.

\section{Meteorological Data for Environmental} Protection - C. H. Hunter

A meteorological data set consisting of daily maximum instantaneous wind speeds for 1993 was prepared for the Environmental Protection Department. This data will be used by a subcontractor to calculate estimates of emissions from SRS coal storage piles from wind-induced erosion. The erosion estimates will become part of the Site's air emissions inventory database. The data set was generated from wind data collected at the 36-meter level of the Central Climatology meteorology tower.

\section{Swamp Hydrologic Modeling - K. Chen}

The SRS swamp area hydrology was modeled successfully using the FASTTABS code on a silicon graphics workstation. An additional case was simulated. The boundary conditions of this simulated case are 12,000 cubic feet per second for the Savannah River flow and 79.5 feet for the river stage at Steel Creek gauge station.

\section{Modification of STREAM Code for Emergency Responses - K. Chen}

STREAM is an emergency response code that predicts downstream pollutant concentrations for releases from the SRS area to the Savannah River. The STREAM code uses an algebraic equation to approximate the solution of the onedimensional advective transport differential equation. The advantage of this simplified approach is that the time required to obtain a solution is shortened to a matter of minutes. However, this approach generates spurious oscillations in the concentration profile when modeling long duration releases.

To improve the capability of the STREAM code to model long-term releases, its calculation module was replaced by the WASP5 code. WASP5 is a U. S. EPA water quality analysis program that simulates one-dimensional pollutant transport through surface water. WASP5 uses a finite difference method to solve the advective transport equation.

Test cases were performed to compare the revised version of STREAM with the existing version. These test cases simulated pollutant transport to Savannah via the Savannah River for releases from the H-Area outfall. For continuous releases, results predicted by the revised STREAM code agree with physical expectations.

The WASP5 code was benchmarked with the U.S. EPA 1990 and 1991 dye tracer studies, in which the transport of the dye was measured from its release at the New Savannah Bluff Lock and Dam downstream to Savannah. The peak concentrations predicted by the WASP5 agreed with the measurements within $\pm 20.0 \%$. The transport times of the dye concentration peak predicted by the WASP5 agreed with the measurements within $\pm 3.6 \%$. These benchmarking results demonstrate that STREAM should be capable of accurately modeling releases from SRS outfalls. This work is presented in SRT-ETS-950427.

\section{Trace Metals in Vegetation Samples-}

\section{P. R. Cable}

The trace metal analysis of 45 vegetation samples collected at various locations on the Savannah River Site was completed. The results were compiled and reported in SRTC-ETS95184. 


\section{SRTC's Climatology Site - R. J. Kurzeja}

A report on the SRTC's Climatology Site is now available for distribution. This report, entitled The Savannah River Technology Center Research and Development Climatology Center (WSRC-TR-93-596), describes the instruments and data collected at the Climatology Site, uses for the data, and future program plans.

\section{Technical Work Control Assessment -} R.M. White, E.A. Nelson

A review of a task by the Materials Technology Section of the Applied Science and Engineering Technology Group of SRTC to determine the corrosion inhibitor requirements of high level waste during salt dissolution operation has been completed. This is part of the SRTC SelfAssessment Program and is intended to measure our compliance with the L1 Manual (SRTC version of the E7 Manual).

\section{Safety Analysis Support - G. Flach}

Groundwater travel times, source attenuation factors and dose factors for postulated contaminant transport from each $\mathrm{H}$-area waste tank to surface water have been computed. The effort complements earlier analyses restricted to $\mathrm{H}$-area tanks associated with the In-TankPrecipitation (ITP) process. Best-estimate groundwater transit times range from 45 to 85 years, while conservative estimates range from 10 to 15 years.

Sanitary Landfill Groundwater Bioremediation Optimization Test - $T$. C. Hazen, K. H. Lombard, M. M. Franck, D. Altman, J. D. Young, C. J. Berry, F. A. Washburn, J. Santo Domingo, C. B. Fliermans, J. Shappell, N. O'Halloren

The well installation and initial soil sampling at both sanitary landfill sites 1 and 2 are complete. Six air/nutrient injection wells (AIW), two vadose zone extraction wells (ASW), 28 piezometer clusters including: 2 vadose zone piezometers, 1 saturated zone piezometer (site 2), 2 saturated zone piezometers (site 1) have been installed to date. Sampling and analysis includes 56 sediment sample points comprising
112 VOC samples, 168 microbiology samples, 56 inorganic analyses, 10 water sample points to determine community structure and 4 preliminary soil gas samples to assist in the instrument calibration. The equipment and instrumentation procured to date include a 300 $\mathrm{cfm} / 100$ psi air compressor, a 500 gal air receiver tank, two $20 \mathrm{cfm}$ vacuum-blowers, two $480 \mathrm{v} / 3$ phase $50 \mathrm{Kva}$ generators, 8 pressure transducers/data loggers, misc. temperature/pressure monitoring devices and a Brüel \& Kjær Type 1302 Infra-red photoacoustic multi-gas monitor. Start-up and testing of the system is scheduled to begin on June 9, 1995. A final DHEC site inspection and approval to start the test is scheduled for June 8,1995. The site safety inspection (SMI 51) will be completed prior to the State inspection. Currently, construction activities have been hampered due to heavy rain making the site inaccessible.

\section{Design of TNX Recirculation Well R.L.Nichols, R.M.White, J.Kupar}

The TNX Groundwater Interim Record of Decision (IROD) calls for the installation a hybrid groundwater remediation system consisting of conventional pump and treat wells and an innovative vertical recirculation well. SRTC is the Design and Technical Agency for the recirculation well. A Site Clearance has been obtained for the recirculation well, monitoring wells and peripheral equipment. The Handi House has been relocated to make way for monitoring well TVM-2.

Detailed Three-Dimensional Flow and Contaminant Transport Modeling of the Old Burial Ground - G. Flach, $M$. Harris, P. Thayer, A. Smits, J. Haselow, L. Hamm,

A detailed, three-dimensional contaminant transport model of the Old Burial Ground has been developed. Initial numerical runs have produced promising simulations of past tritium discharge to Four Mile Branch. The model is currently being refined and evaluated through comparisons to various field data. Following calibration, the model will be used to predict future tritium discharge to Four Mile Branch under various remediation alternatives including no action and capping. 
RADMAPS Radiation/Position Detection Unit - K. J. Hofstetter and D. W. Hayes, R. F. Eakle

The Scout portable 256-channel multichannel analyzer was tested in the field with a $1 " \mathrm{x} 1^{\prime \prime}$ $\mathrm{NaI}(\mathrm{Tl})$ detector. This system uses a HP100LX palmtop computer to store spectra which can be downloaded to a PC using a standard serial communications interface. Software was developed to analyze the resulting spectra into their radioisotopic components. This system was field tested as part of the RADMAPS project to develop analysis methods for scintillation spectra.

Biotechnology Group Aids Local County Landfill - T. C. Hazen, B. Skwarek

As part of the industrial assistance program the Biotechnology Group is evaluating the Columbia County Landfill and preparing a list of options that may aid them. Columbia County Board of Commissioners asked DOE for Biotechnology Group assistance due to their national reputation in the area of bioremediation. It is felt that bioremediation strategies may increase the life of the landfill and allow some areas to be reclaimed or reused.

Phase-Out of the Savannah River
Integrated Demonstration - C. A.
Eddy-Dilek, T. C. Hazen, E. L.
Funderburk, R. N. Sims

A complete set of the technical documentation completed during the SRS Integrated Demonstration for Cleanup of VOC at Non-Arid sites was collated and sent to RAPIC. RAPIC, The Remedial Action Program Information Center, at Martin Marietta Energy Systems has agreed to serve as the distribution center for all of the documentation completed during the Integrated Demonstration. The purpose of this center is to provide technical information support to all DOE Environmental Restoration Programs and program participants. Any of the technical documents produced during the Integrated Demonstration will be available for distribution. The contacts for this service are Lola Estes or Park Owen, RAPIC, Martin Marietta Energy Systems, Building K-1210,
MS-7256, Oak Ridge, TN, 615-241-3098. Three boxes of original documents and thirty five boxes of copies were shipped.

A short animated video sequence of the data from the bioremediation demonstration completed during the Integrated Demonstration was completed. This sequence simultaneously displays concentrations of microorganisms, concentrations of the primary contaminant TCE, the clay content of the sediments, and chloride concentrations during the in-situ bioremediation demo has been completed. The bioremediation process promotes the release of an enzyme by methanotrophs during metabolism of methane. This enzyme interacts with and degrades the solvent TCE to carbon dioxide, water, and chloride ion. This process is especially effective in clay rich zones of the subsurface. This video sequence graphically shows the complex interaction between these variables throughout the remediation demonstration.

Radionuclide Assessment of the Arctic Ocean - D. M. Beals

The Environmental Technology Section is performing radionuclide analyses of samples collected by the U.S. Geological Survey (USGS) in the Arctic Ocean, and supporting a sampling trip led by the USGS to measure radionuclides in the $\mathrm{Ob}$ and Yenisey Rivers in Russia. Results of high resolution gamma spectrometry analyses of sea ice rafted sediments in the Arctic Ocean show that the sediments originating near the Former Soviet Union (FSU) have significantly more activity that those originating near the Alaskan coast (SRT-ETS-95-146). During the week of 10 April, ETS participated with the USGS in a test run of sampling equipment to be used during the Russian rivers expedition. The test was performed on the Mississippi River; USGS personnel were instructed on the operation of ETS sampling equipment. Samples will be returned to ETS this summer for analysis and interpretation.

Characterization and Monitoring of DNAPL's - B.B. Looney, J. Rossabi, K.M. Jerome, R.M.White, B. Van Pelt

A draft scope of work was prepared for the Resonant Sonic sub-contract to do vibratory 
Progress and

cone penetrometer testing in the M-Area. This technology has been successfully demonstrated at Hanford and offers the potential to penetrate to greater depths than can be accomplished with conventional technology.

A draft scope of work was prepared for a subcontract with Aprotek, the supplier of the Oleofilter. This is a coalescing filter incorporating an amine coated hydrophilic granular media claimed to adsorb emulsified hydrocarbons. The Oleofilter is needed to improve our capability to treat the groundwater that we will extract from the ground during the alcohol injection/ extraction tests planned this year. Without treatment we may not be able to send the water to the M-1 stripper because of PCB contamination. A number of alternative technologies that may be applicable have also been pursued.

Demonstration of Mag-Sep Technology for the Extraction of Radionuclides from Aqueous Media - D. M. Beals, J. P. Bibler

Laboratory tests are nearing completion on extraction of Tc-99 from fresh and seawater using Mag-Sep technology. The kinetics of uptake of Tc-99 from water is very rapid and nearly complete (greater than $98 \%$ uptake within 30 minutes using 1 gram of particles in a 1-liter sample; SRT-ETS-95-150). The first field test was performed in a sampling trip to the Mississippi River. Particles coated to extract cesium from solution were received and characterization testing is underway in the lab. A proposal has been written to the Office of Technology Development for continued funding for field studies for analytical and clean up applications.

\section{Rapid Bioassessment Techniques}

\section{H. Paller}

M. H. Paller was invited to participate in a workshop on aquatic biomonitoring techniques. The workshop was attended by personnel from South Carolina universities, natural resource agencies and regulatory agencies with the objective of identifying biological monitoring techniques to assess the environmental quality of surface waters. The OTD funded research in the use of biological indicators of stream health was discussed.

\section{European Tracer Experiment (ETEX)} D. P. Griggs

The Joint Research Centre of the Commission of the European Communities requested each organization that participated in the real-time modeling portion of ETEX (including ETG) to perform an "a priori model evaluation". This exercise is designed to "gauge the degree of confidence each participant places in their model predictions" prior to the comparison of model results with actual measurements. ETG was requested to supply estimates of the expected error in the model predictions made in October and November 1994 during the ETEX campaign. Specifically, ETG was requested to estimate an uncertainty range for the maximum plume concentration and plume arrival time at ten of the European monitoring stations. After reviewing the locations of the specified stations, ETG scientists selected the predictions for the October 23, 1994 ETEX release as the basis for the uncertainty estimate. The predictions for this event were reviewed and subjective uncertainty ranges were estimated at the ten locations for the two parameters. The uncertainties were placed in the requested format and faxed to the offices of the Joint Research Centre in Ispra, Italy, prior to the deadline of April 30. 1995.

\section{Biodegraders in TNX Organic Removal} Facility - C. Berry, J. Kastner, J. Santo Domingo

The TNX has experienced a reduction in benzenes by the Organic Removal Facility (ORF) that far exceeds the adsorption capabilities of the activated carbon. Upon examination, the carbon was found to contain a dense biofilm with large number of bacteria. Isolation of benzene and chlorobenzene degraders from ORF samples is under evaluation. Evidence of degradation of these compounds by potential degraders will be obtained using gas chromatography. In addition, chemostat cultures active in benzene utilization are being studied in an effort to further establish that benzene disappearance within the columns is a biological process. Microbiological characterization of the chemostat communities will be performed using 
ribosomal probes and $\mathrm{CsCl}$-bisbenzimide gradients.

\section{MAG*SEP Demonstration - K. Jerome,} R. Nichols, M. Phifer, F. Sappington, Miles Denham, C. Betivas,

\section{J. Bibler}

The MAG*SEP Demonstration will provide for the development, design and first field tests of two new technologies; the Magnetic Separation System, referred to as the MAG*SEP system, and the EnviroWall Barrier. Savannah River is hosting the demonstration and providing process chemistry support, and all site support and site characterization.

Site selection criteria was received from ANL after which a search for a site monitoring well from which to conduct the MAG*SEP demonstration was performed. The only monitoring well located at SRS meeting all the criteria is well DCB-4A (located at the D-Area Coal Pile Runoff Basin). WSRC personnel began monitoring/testing of that well for groundwater chemistry. Testing continues through the present.

Approval has been received from EPD for disposal of the barrier wall pump test water into the D-Area Coal Pile Runoff Basin. The Treatability Study Workplan for the MAG*SEP was submitted to EPA and SCDHEC on April 26.

Ongoing activities of significance include the continued construction of the barrier wall by BMC Corporation. Projected completion is mid to late June. WSRC staff is providing oversight of the construction activities. The Process Hazards Review of the MAG*SEP treatment system is on hold pending completion of the process chemistry and redesign of the regeneration system.

Bioremoval of Metals - E. W. Wilde, J. Radway

A new Technical Task Plan expanding the scope of the bioremoval of metals project was developed and sent to OTD-HQ. The project will be expanded from an evaluation of algae embedded in foam for bioremoval of heavy metals to an evaluation of the Frisby foam as an immobilization medium for a variety of biomass types (including bacteria and fungi) for use in remediating a variety of pollutants including TCE, PCE, BTEX, and radionuclides in addition to heavy metals. 


\section{WASTE MANAGEMENT}

\section{E Area Vaults and Burial Ground Complex Interaction Study - J. R. Cook, E. L. Wilhite}

The Radiological Performance Assessment(RPA) for the E Area Vaults Disposal Facility was recently approved by DOE-HQ subject to several conditions. To date, this is the only RPA approved in the DOE Complex. One condition was that a study be conducted to estimate the effect of adding releases from existing disposal facilities to the calculated releases from the E Area Vaults, and the impact on vault disposal limits. The RPA excluded any consideration of the existing Burial Ground Complex adjacent to the site of the E Area Vaults. Several review agencies have indicated that a study of the potential interaction of contaminant releases should be performed. IWT has completed an initial interaction study, which indicates that tritium and U-238 have the potential to exceed the performance objectives for the $\mathrm{E}$ Area Vaults during the time of compliance. Futher work using the more rigorous approach developed in the RPA is recommended to determine if lower vault disposal limits are needed.

Soil Release Guidelines -E. L. Wilhite, J. R. Cook, R. H. Hsu, A. D. Yu

The E Area Vault Radiological Performance Assessment, completed in April 1994 by IWT, evaluated a more cost effective method of diposing of contaminated soil-shallow land burial instead of vault disposal. The

Assessment showed that if the nuclides in the soil fell below certain limits, the soil could be disposed via shallow land burial. Solid Waste Management has recently issued a Soil Management Plan and a new WAC allowing an SRTC recommended method for soil disposal. This will impact disposal of an estimated 12,000 cubic feet of soil per year. Anticipated savings are $\$ 360 \mathrm{~K} / \mathrm{yr}$.

IWT has recently completed a study on soil release guidelines for SRS suspect contaminated soil. A computer code developed for DOE, RESRAD, was used to determine intruder scenario concentration limits based on different disposal options. These values were compared with values calculated from EPA drinking water Maximum Concentration Limits(MCLs) and the $4 \mathrm{mrem} / \mathrm{yr}$ drinking water guide. Results from this study have been used to recommend a more cost effective way to dipose of soil at SRS(up to 80,000 cubic feet per year). Potential cost savings of $\$ 600 \mathrm{~K} / \mathrm{yr}$ are anticipated by free releasing this soil on the Site instead of disposing of it via shallow land burial.

Solid Waste Management is in the process of implementing this change.

CIF HEPA Prefilter Status - D. B. Burns, A. Wong, B. W. Walker

The Off-gas Components Test Facility(OCTF) is a $1 / 10$ scale pilot facility at TNX, which is being used to evaluate the operating performance of the CIF off-gas system. Results from recent OCTF tests suggest that the HEPA prefilter life will be much shorter than practical(possibly as short as 1-3 days). A task team was chartered by Solid Waste to better understand the problem and recommend solutions. SRTC has participated on this task team. The task team presented their findings $5 / 12$, which will result in the following activities for the OCTF in the near future:

- Measure the relationship between salt concentration in the quench water and scrubber emissions and HEPA prefilter life.

- Measure the improvement in scrubber emissions when the scrubber steam flow is increased by $2 X$.

- Measure the improvement in scrubber emissions when the scrubber water flow is increased by $3 \mathrm{X}$.

- Evaluate a cleanable HEPA prefilter that is compatible with the existing housing.

CIF Kiln Seal Test Unit - D. L. Fisher 
A 2/5 scale of the CIF rotary-kiln seal is being tested at TNX. Performance, operating, and maintenance information from testing is being supplied to Solid Waste Engineering to support CIF kiln start-up and operation. Initial testing of the CIF Kiln Seal Test Unit established baseline air influx rates through the seal in static and rotating modes. Air pressure to the seal's pneumatic calipers was varied to provide a map of the seal's response thoughout its range of operation. With chamber pressure controlled at -0.5 inches water column, static influx rates were 3 to $5 \mathrm{scfm}$ (per sq. $\mathrm{ft}$ of seal) across the range of seal-face pressures. Rotating the seal decreased influx by $1 \mathrm{scfm}$ and heating it yielded further improvement. Four test series were conducted to determine optimum seal-face pressures. An optimum face pressure of $1.5 \mathrm{psi}$ was determined, with only slightly better $(10 \%)$ sealing at face pressures twice as high. A strategy for setting the seal-face pressure was also recommended. Wear tests(in the final portion of the test program) will be used to validate or refine these recommendations.

\section{ESP Support - M. S. Hay}

The Tank $51 \mathrm{H}$ sludge for the Batch 1 demonstration in 773-A Shielded Cells has been adjusted and analyzed. Preliminary and analytical results were documented in SRTLWP-95-033. DWPT personnel will use the results in PCCS modeling to determine the sludge, PHA and frit ratios. The adjusted sludge composition was consistent with previous analyses of Tank $51 \mathrm{H}$ sludge samples obtained in 1988. The 1988 sludge sample has slightly lower iron content and slightly higher aluminum concentration than more recent slurry samples obtained during the Process Verification Tests in ESP. Overall, the sludge feed for the Batch 1 demonstration is very similar to the expected composition for the ESP sludge feed to DWPF with the sludge washed to $9 \mathrm{wt} \%$ sodium.

Radiolytic Generation of Hydrogen and Benzene - D. D. Walker

The yields of free and trapped hydrogen and free and trapped benzene from the irradiation of tetraphenylborate slurries in concentrated salt solutions have been measured. The observed yields in concentrated salt solutions are lower than those predicted in the Tank 48H TCLFL safety calculations, confirming that the calculations are conservative. No trapped hydrogen was found in irradiated sodium tetraphenylborate solids. Free hydrogen yields in the presence of high concentrations of nitrate and nitrite salts were found to be linear with dose, with an average G-value $0.023 \pm .015$ molecules $/ 100 \mathrm{eV}$. Irradiation of dry NaTPB ${ }^{-}$ solids or slurries containing solid NaTPB released "trapped" benzene when the solids were dissolved in water or in dilute salt solutions. However, the observed yields were less than $3 \%$ of the conservative values used in. the Tank 48H TCLFL calculation. Free benzene yields did not increase linearly with dose, but are conservatively bounded by the Tank 48H TCLFL calculation. A preliminary report of these results has been issued (WSRCTR-95-084).

Possible Explosive Compounds in the Savannah River Site Waste Tank Farm Facilities - D. T. Hobbs

The report, "Possible Explosive Compounds in the Savannah River Site Waste Tank Farm Facilities (U)," WSRC-TR-91-144, revision 1 was issued on $4 / 28 / 95$. This extensive revision to the 1991 report incorporated additional experimental work and addressed comments from technical review panels. Key findings and conclusions reported in the document are summarized below.

Based on a comparison of the know constituents in high-level nuclear waste stored at the Savannah River Site (SRS) and explosive compounds reported in the literature, only one class of explosive compounds, organics, have been identified as requiring further work to determine explosive hazards and impact on tank farm operations. This class has been adequately addressed for past and current tank farm operations. However, the Defense Waste Processing Facility (DWPF), a new facility to be started in the near future, will send organic compounds to the tank farm that are known to be explosive under certain conditions. Studies are in progress to determine the concentrations of these compounds, and what controls, if any, are needed before this waste is received into the tank farm. 
Of the fourteen classes of explosive compounds identified as conceivably being present in tank farm operations, ten classes--metal fulminates, metal azides, halogen compounds, metal-amine complexes, metal NOx compounds, nitrate/oxalate mixtures, metal oxalates, metal oxohalogenates, metal cyanides/cyanates, and peroxides--are not a hazard because these compounds cannot be formed or accumulated in sufficient quantity, or are not reactive at the conditions that exist in the tank farm facilities. Three of the classes--flammable gases, metal nitrides, and ammonia compounds and derivatives--are known to have the potential to build up to concentrations at which an observable reaction might occur. Existing controls limit the formation or concentration of these classes of compounds.

ESP Slurry Pump Modifications - M. J. Dalmaso, D. B. Stefanko

IWT is coordinating the modification and testing of three replacement slurry pumps for Tank 51 . The pumps will be modified and tested at TNX prior to installation into the waste tank. Activities completed this reporting period include:

- The first pump was disassembled, inspected, reassembled, and installed into the TNX test stand.

The second pump was disassembled, inspected, and reassembled. The upper shaft and stuffing box bearing were severely damaged from what appears to have been dry running. The shaft had about a 1/4" deep groove worn in it and the bearing was burnt. Both the shaft and bearing have been replaced.

- Two motor stands were delivered to TNX along with the piping and fittings for the motor stand piping.

- Piping on the first motor stand was done and the stand, along with a motor, installed on the first pump.

The draft test procedure was prepared and sent out for review and comments.
The path forward includes leak checking the second pump, piping the second motor stand, and performing a run-in test of the first pump. Testing of the first pump could start as early as $5 / 8$.

\section{WSRC/WHC Pump Development Program - M. J. Dalmaso}

WSRC and WHC (Westinghouse Hanford Company) are cooperating in a program to procure and test a new slurry pump design for use in High Level Waste Tanks. The intent is to obtain a design which eliminates problems associated with the current pump design. WHC is responsible for procurement of the prototypes. Activities completed during this reporting period include:

- Design contracts were awarded to the Westinghouse Electro-Mechanical Division in Cheswick, PA and Lawrence Pumps, Inc. in Lawrence, MA. The Westinghouse design is a canned motor pump, and the Lawrence design is a line-shaft pump with anti-friction bearings and a gas filled column. Because of funding limitations, the contracts were awarded at a $60 \%$ funding level. Performance of these contracts is approximately five months. The initial design will be for a pump sized for the TNX test stand, as current plans are for the testing to be done at SRS.

- Kickoff meetings were held at the vendor's facilities. The purpose of these meetings was to review the technical specification in detail and clarify any areas of confusion. A schedule was also outlined and the required deliverables discussed.

The path forward is for IWT to participate in the design reviews with the vendors, and begin establishing a test program with WHC and SRS personnel.

TNX Off-gas Components Test Facility D. B. Burns, R. K. Roberts, A Wong

The TNX Off-gas Components Test Facility (OCTF) is a $1 / 10$ scale pilot facility which is used to evaluate the operating performance of the Consolidated Incinerator Facility (CIF) off- 
gas system. Activities completed during the reporting period include:

- Completed the first two runs of the HEPA filter life test. The test parameters were: $10 \%$ salt in the quench tank, no salt in the scrubber tank, and no particulate injection into the burner. Preliminary data indicated that the HEPA prefilters were not capable of delivering the expected service life (months) under such harsh conditions. The next run will test the HEPA prefilters in a less demanding environment.

- Boroscoped the interior of the quench vessel, the scrubber, the cyclone, and the FRP duct at various locations to determine the souce of insulating material that has repeatedly plugged the duct drain. The equipment appeared to be in good condition and free of foreign objects.

- Assembled the particulate sampling equipment and utilized it during the HEPA test.

The path forward includes completing the rest of the HEPA life test to identify the operating envelope for the HEPA prefilters and thus quantify expected filter service life.]

\section{SRS Draft Site Treatment Plan - L. Williams}

The Savannah River Site (SRS) is developing a Site Treatment Plan (STP) for mixed waste streams to comply with the Federal Facility Compliance Act (FFCAct) of 1992. The STP addresses waste treatment options to meet regulatory land disposal restrictions (LDR).

A proposed STP (PSTP) was signed by the President of WSRC on 3/20. This was a major milestone towards obtaining SCDHEC approval of the STP and compliance with the FFFAct by 10/95. The path forward is to continue working with the STP Task Team (as needed) to ensure the PSTP is approved by the SCDHEC.

\section{High Level Waste - Malcolm Kyle}

EES has completed the design work for the Waste Tank Interior Video Inspection System.
Fabrication of the deployment cable reel and the camera housing will begin within the next few weeks.

EES provided HLWE with a small-diameter, water-resistant camera and light for inspecting spray rings inside the $2 \mathrm{H}$ Evaporator pot.

EES delivered a portable camera system to the ${ }^{-}$ New Waste Transfer Facility for use during remotability testing. The camera system will be returned upon completion of testing.

EES is fabricating the electrical controls for the ITP Tank 48 Instrumentation project. The data acquisition software for reading the thermocouples is operational but is being modified to include controlling the gas chromatograph.

EES is currently fabricating six RS-485 to BCD converters for the ITP Reel Tapes. One of the converters will the completed by June 2 , and the remaining five are expected to be complete by the first of July.

\section{Defense Waste Processing Facility Malcolm Kyle}

EES is continuing the Analytical Cell Upgrades for DWPF. The final design of the penetration seal was completed per the schedule and given to the customer for review. Comments were incorporated into the drawings, and fabrication is scheduled to be completed by June 21 . The penetration cable wiring diagrams for all three cells have been completed, and the cable block diagrams are in progress. Additional design discussions were held with Bechtel construction regarding conduit runs and cell penetration seal installation.

A prototype of the cell services tubing for the right side of cell 3 was used successfully in the mock-up. Prototypes of the panel box and the modular adapters were also used. Minor design modifications are underway, and the final design is expected to be completed by June 13 .

Fifty percent of the internal junction boxes have been received, and the remainder of the order has been placed. The configuration and location of receptacles on the junction boxes is complete, and fabrication has begun. 
EES is progressing with the DWPF Melter Pour Spout Modification Project. A purchase requisition for the Tele-manipulator has been issued. Three vendors have shown interest in bidding for the Tele-manipulator, and a pre-bid meeting with the vendors was held. Detail design work for Pour Spout Camera and Bellows Adapter is on schedule. Thermal analysis on the existing Pour Spout Adapter has been completed, and a thermal analysis on a new Bellows Adapter design is in progress.

EES has completed purchase requisitions for all Canister Level Detection System components. Requisitions for the infrared camera system, level indication computer, and video manipulation unit have been placed, and all of the support hardware (amplifiers, monitors, etc.) has arrived on site. EES supplied a 19" rackmount cabinet to house the computer system and video amplifiers. The DWPF Control and Production Systems Group will purchase and modify pre-existing level detection software to generate a $4-20 \mathrm{~mA}$ output for the DCS. EES is arranging for the designer of the West Valley infrared camera level detection system to visit the site and relate to the SRS system designers and operators what was required to put together an operational system at West Valley.

EES completed the installation of the Gas Chromatograph on the mezzanine level of DWPF on May 19. Following the installation of sample pipes, pumps, and controls by Bechtel Construction, testing of the Gas Chromatograph will begin.

EES and Late Wash completed a technical review of the Field Termination Cabinets design, and two major issues were resolved. One issue was to determine the appropriate method for labeling the internal wiring of the cabinets for compatibility with PDMS. EES will provide an estimate for adding PDMS jumper ID's to the termination database and for purchasing the label making software and labels. Bechtel Design will enter the EES termination labels into their PDMS database. The second issue involves determining the correct method for terminating the ground from the field for $120 \mathrm{VAC}$ discrete inputs powered in the field. After a review of DOE standards,
NEC standards, and site practices, it was determined that a third conductor ground would not be run with the discrete AC signals. The cable raceways will provide the earth ground path. Late Wash has applied for an exception from DOE order $6430.1 \mathrm{~A}$ to not run three conductor cable for discrete signals.

EES is continuing development for the Benzene ${ }^{-}$ and Nitrite Analyzer Systems for Late Wash. Fabrication of the operator interface control station is $75 \%$ complete, and glovebox modifications will be done in 717-A. All drawings have been completed and delivered to the customer for approval. A draft version of the software requirement specification has also been completed. 


\section{GENERAL}

\section{Change Control Status - L. R. Chandler}

The current status of the Baseline Change Proposal (BCP) packages developed by SRTC for the FY95 Annual Operating Plan is: thirty have been prepared; two are routing in SRTC for approval; two are awaiting DOE approval; twenty-six have geen approved by DOE; and seventeen have been entered into the FY95 AOP electronic data base.

\section{Thermal Analysis of Melter Riser - S. J. Hensel}

Melter testing has revealed a cool spot in the melter riser near the melt pool. A 3-D conduction analysis of the riser and near wall melter agrees qualitatively with temperature measurements. Further model enhancements are required to achieve better agreement with the measured temperatures. Analyses of potential riser design modifications will be made upon completion of model enhancements.

\section{Melter Pour Spout - R. A. Dimenna and} M. A. Shadday

DWPF recently requested that ATS develop a dynamic model of the DWPF melter pour spout to help identify the cause of oscillations in the control pressure during a test pour. Simple physical models were developed to represent the key features of the pour spout and the associated control systems. These models were tested to show their ability to capture such behavior as glass level in the riser section of the pour spout, glass level resporise to changes in the bellows set point pressure, response of the pressure control system to changes in proportional and derivative control constants, and response of the control system to initial heat up of the glass canister when flow first begins. Transient behavior of the simple models indicated that we would be able to represent system behavior which was qualitatively similar to that seen during the oscillations in the test pour. Work during the next month will focus on coupling all of the models being developed and determining the sensitivity of the overall melter pour: spout system to variations in controllable parameters.

Durability of DWPF Glasses Within the Purex Range of Compositions -

T. B. Edwards

Processing in the Defense Waste Processing Facility (DWPF) is controlled by constraints on predicted properties of the product glass. One of these properties is chemical durability. which is measured as the response of various glass constituents to the seven-day Product Consistency Test (PCT). As currently. implemented into the DWPF's Product Composition Control System (PCCS), the response of boron is taken as representative of all of the constituent responses, and control is in terms of the boron response. This response, in normalized units and in log scale, is taken to be a linear function of the glass's free energy of hydration, DGp. DGp is a parameter which represents the sum of influences on durability of the various glass oxide components.

This generalized relationship between the normalized Product Consistency Test boron release and the free energy of hydration of a glass has been documented by the Glass Technology Group. It appears to underpredict releases for glasses in the so-called "Purex" range of compositions which comprises a worst-case DWPF operating range. A methodology similar to that used for the generalized study was employed in a joint effort with A. L. Kielpinski of the Glass Technology Group to develop a linear relationship specific to these Purex compositions. An upper tolerance limit for this relationship was used to determine the minimum value of DGp (-7.44 $\mathrm{kcal} / \mathrm{mol}$ ) which will yield acceptable durability. Purex compositions to be processed in DWPF must be such that their DGp's exceed this value.

The results of this analysis were issued jointly by Applied Statistics Group and Glass Technology Group in technical report WSRCTR-95-0209.

TFL Electrochemical Reactor Pilot Plant - J. L. Steimke 
The electrochemical reactor has been ordered from Electrosynthesis Co. Delivery should be in mid July. The 1500 ampere DC power supply for the power supply has been delivered to the TFL. The power supply will be connected to an automatic shutdown circuit because it will be necessary for the reactor to operate for extended periods unattended. An existing shutdown circuit was modified to accommodate the Electrochemical Reactor.

A safety analysis for the Electrochemical Reactor Pilot Plant was presented to the SRTC Facilities Operating Safety Committee (FOSC). The FOSC accepted the Safety Analysis but required the completion of some safety related work to be done in addition to two documents already written, the Environmental Evaluation Checklist and the Screening Process Hazards Review. The additional items are a Request for Air Permit Exemption, a plan for the disposal of the approximately 2000 gallons of waste to be generated during testing and a Hazards Assessment Document (HAD). The Air Permit Exemption was written and forwarded to the South Carolina Department of Health and Environmental Control. When approved, it will authorize the release of specified amounts of gases to the atmosphere. A plan for disposing of most of the waste has been completed, but final negotiation on the composition of the waste proceeds. Work on the HAD proceeds. The HAD satisfies a DOE Order requiring the classification of degree of potential hazard for a facility, based on the inventory and type of chemicals involved.

\section{Ton Cask Evaluation - P. B. Blanton}

A TAR was utilized to obtain the assistance of VECTRA, Inc, in the execution of the task. The kick off meeting was May 9. VECTRA will provide a report of the results of their analyses June 9,1995 . Additional meetings were held with VECTRA for both progress reports and information exchange on May $22 \&$ 26. P\&TG met with RE May 16. Points of contact were identified (several changes occurred in the RIF), and the task scope was reaffirmed. RE is pursuing a Change Control action to expand the scope of the task to include a complete Packaging Safety Assessment.

The following documents were written:
1. On-Site Radioactive Material Packaging Assessment of 70 Ton CD Shipping Cask Task Technical Plan (U), SRT-PTG-950048

2. On-Site Radioactive Material Packaging Assessment of 70 Ton CD Shipping Cask Quality Assurance Plan (U)SRT-PTG-950049

3. "SRS 70 Ton rail Cask History and Use (U)," SRT-PTG-95-0050

4. On-Site Radioactive Material Packaging Assessment of 70 Ton CD Shipping Cask, Technical Assistance Request Number SRTPTG-95-D041

Beginning in late April, P\&TG has been assisted on this task by R. N. Lutz, SW\&ER.

\section{WSRC Five Year Plan - L. R. Chandler}

The FY97 Five-Year Plan (FYP) has been developed by WSRC for DOE. SRTC has provided programmatic and budgetary input to the Plan which will be structured in the same format used for the FY 1996 Five-Year Plan. The publication format has been chosen to ensure that the Plan will be useful to the various WSRC Programs as a management tool, meets the DOE-SR requirements for structure and reporting, and fulfills the requirement for user friendliness. The Plan will be published in one volume, the Executive Summary, will provide summary information at the Program Level (WBS Level 2). This volume will be divided into plan assumptions, plan structure and development, an overview of the plan, program summaries, line organization division/department overhead (indirect support), support organization division/department overheads, and G\&A strategies.

The SRTC effort began in December 1994 with the delivery of the DOE Call for the Plan. The Call contained DOE-HQ programmatic guidance for WSRC development of the Plan. Work activity since then has included SRTC development of a detailed work schedule, preparation of input data forms, programmatic and budget input preparation by all SRTC organizations, and the delivery to DOE of certain draft input for review. The final output will include the WSRC FY97-2001 Five Year Plan, the FY97 Outyear Budget, Site Development Plan, numerous other Site reports 
and plans and the EM priority work list for FY97.

DOE-SR program personnel were supplied a draft set of all Task Description Sheets (TDS), Level 3 and Support Organization Summaries (SOS) in late May, the SRTC Divisional Planner has supplied copies of the SRTC TDS and SOS sheets to SRTC Level 1 and 3 Managers. These Managers will also receive a copy of the Executive Summary. This should provide the Managers with the basic 5YP output.

SRTC Technical Area OSR Revision Package - (C. L. Smith, S. P. Tinnes)

A SRTC Technical Area Operational Safety Requirement (OSR) revision package has been approved by WSRC and submitted to DOE-SR for approval on 5/31/95.

The proposed OSR revisions are :

- Remove all Nuclear Incident Monitor (NIM) requirements in the SRTC Technical Area, with the exception of the Building 773-A, F-wing NIMs (to monitor the SED facility activities) and the Building 776-2A NIMs (to monitor the high activity waste tanks).

Remove the Building 773-A, F-wing diesel generator requirements, which provides emergency power for the Fwing ventilation exhaust system. The F- wing ventilation exhaust system is not required to mitigate consequences to any accident scenarios to within acceptable limits, and consequently, requirements were previously deleted from the OSRs.

SRTC Technical Area Preliminary Hazards Analvsis - W. J. Copeland, S. P. Tinnes

A draft Preliminary Hazards Analysis (PHA) for the SRTC Technical Area that depicts SRTC in the 1994-1995 time frame has been prepared for WSRC review. The purpose of the PHA is to support the Basis for Interim Operation (BIO) for SRTC in accordance with the requirements of DOE Order 5480.23 and DOE-STD-301194.

The hazards were identified and evaluated in accordance with the guidance provided in DOESTD-3011-94 and WSRC Procedure Manual 9Q.

\section{SRTC Technical Area Basis For Interim Operation (Bio) - S. P. Tinnes}

Revision 1 of the draft SRTC BIO has been completed for WSRC review. The revised BIO addresses DOE-SR comments on the original BIO (DOE Review draft issued November 1993) and completes the annual upgrade requirements for the $\mathrm{BIO}$ per the latest $\mathrm{BIO}$ guidance in DOE-STD-3011-94. A new Preliminary Hazards Analysis (PHA) has been prepared to support the revised BIO (see the above item).

SRTC Building 773-A Fire Accident Analysis - S. P. Tinnes

A SRTC Fire Accident Analysis team has been formed to complete a Fire Accident Analysis (FAA) for Building 773-A (the main SRTC Laboratory), as part of the nuclear facility Safety Analysis. The "Lessons Learned" and "Path Forward" developed from the ongoing 772-F (Central Laboratories) Fire Risk Assessment (FRA) will be applied to this work. The team consists of S. P. Tinnes (SAR Lead), S. J. Robertson (Accident Scenario Development Lead), H. A. Ford (Frequency Determination Lead), D. K. Allison/C. C. Fields (Source Term Calculation Lead), J. M. East (Dose Projection Lead), and J. R Tucciarone (Facility Lead). Dependent upon funding, a draft FAA should be completed for review in September 1995.

\section{Reactor Support - Malcolm Kyle}

EES delivered all components for construction of an air-driven vacuum system to $105-\mathrm{K}$ as part of the Disassembly Vacuum System. EES is providing field assistance as required for equipment assembly and setup.

The submersible electric pump and associated equipment were delivered to TNX for testing prior to deployment on the basin vacuum 
system. The test date is currently set for early June, and power cart fabrication is scheduled to be completed at the same time pending delivery of power disconnecting devices for the cart.

EES worked in conjunction with Components Handling personnel to set up neutron counting equipment needed for blackness testing the 70T shipping cask in 105-P. The cask will be used to move fuel between basins as part of the reactor fuel consolidation program.

EES designed and fabricated a filter hose canister to simplify deployment and retrieval of the C-Area Decon Facility Filter Hose. Use in the field will be by personnel working in plastic suits in contaminated areas, and the new canister design greatly reduces the time and manpower required when using these hoses.

\section{Site Robotics Support - Ivan Lewis}

EES, Separations, and Construction personnel successfully removed the elbow section of the FB-Line ventilation duct on May 21 using the elbow removal pipe crawler system. EES and Separations have scheduled a lessons learned meeting as follow-up to the job.

EES specified two versions of an on-crane remote video system for the DWPF Late Wash facility. The two versions were based on highly simplified wiring techniques and optical through-the-air techniques for video and control transmission respectively. Area personnel will select the system of choice. In both cases, nonradiation hardened, but robust, equipment has been specified. This is expected to have a longer crane life than the radiation hardened versions since vibration is a much greater hazard than radiation in this particular application.

EES completed the re-engineering of the existing DWPF Melter Borescope with the issuance of record drawings on the now installed units. This will allow the acquisition of the planned Melter \#3 Borescopes to proceed. The second phase of the DWPF Borescope work has begun, and optics redesign is nearing completion at the University of Alabama Optics and Laser Department. This design will be incorporated into changes in the Inconel 690 protective jacket by EES. The combined changes should significantly improve the image quality and the low light sensitivity.

EES completed and released in draft form the procurement specification for the DWPF Melt Cell Manipulator. The draft release was a critical schedule item. The purpose of the new manipulator which will replace one of the existing melt cell manual manipulators is to perform several routine operations that are pushing the limits of the manual manipulators and to provide a method for recovering from a melter pour spout pluggage. The telerobotic manipulator will have a payload capacity of 125 lbs and a reach of approximately 15 feet. It will be equipped with several tools capable of removing solidified glass.

\section{Robotics for D\&D - Ivan Lewis}

EES, at the request of Dr. Clyde Frank (EM50), demonstrated SIMON and SWAMI at the "Innovative Environmental Technologies Conference and Demonstration: Environmental Technology and Training 2000". The conference was held in Beckley, WV on May 22. SIMON demonstrated autonomous radiation floor surveying, and SWAMI demonstrated autonomous navigation, drum bar code label reading, and image capture.

\section{Office of Technology Development - Tank Focus Area- Ivan Lewis}

EES issued for fabrication the final designs for the two Light Duty Utility Arm (LDUA) End Effectors: the Optical Alignment System (OAS) and the Stereo Photography System (SPS). Fabrication and assembly of the Overview Video System, developed for observing the operation of the LDUA, is nearing completion. The system will be shipped to Hanford when testing is finished.

\section{Office of Technology Development - D\&D Focus Area - Ivan Lewis}

EES presented a progress report to DOE-HQ and METC personnel coordinating the Facility Deactivation, Decommissioning, and Material Disposition Focus Area on the EES concept of standardized tools for shielded cells dismantlement. Partnering arrangements with 
private industry for actual tooling development are underway.

\section{Technology Transfer - Ivan Lewis}

EES delivered three prototype units of the second-generation Jaundimeter, an EES invention which uses optical technology to detect and diagnose neonatal jaundice. The units were delivered to FONET, Inc. of Clearwater, Florida as part of an ongoing CRADA. FONET will conduct clinical testing to validate the operating principle of the devices, measure their reliability under field conditions, and identify needed improvements. If the tests are successful, FONET plans to market the units under the trade name of "Jaundi-Check."

EES met with EXXON and DART Technical Services Representatives in New Jersey on May 22 to discuss using the EES-developed FERRET technology to perform eddy current inspection of 4 " carbon steel piping. The FERRET is currently designed for 2 " piping systems. Also, B\&W Nuclear Services maintains their interest in the FERRET technologies as a platform for ultrasonic examinations. 


\section{ITEMS OF INTEREST}

Modern Applications News magazine featured the EES-developed plasma torch cutting crawler in an article and cover picture for its May issue.

EES Robotics presented to DOE-HQ EM-63 visitors on robotics transferable technology.

EES Robotics gave a presentation and tour for the Minister of Environmental Protection and Nuclear Safety for the Ukraine.

EES Robotics demonstrated SIMON as part of the DOE-SR Take Your Child to Work Day.

EES hosted the 1995 Class of Leadership Aiken County in a tour of the site and the Robotics Laboratory on May 9.

E.A. Nelson was appointed Adjunct Professor in the Entomology Department at Clemson University.

Roger White attended a one day seminar on cone penetrometer testing sponsored by ConeTec.

E.A. Nelson served on a Technical Review Panel to review the next Five Year Program Plan for the Center for Forested Wetlands, Charleston, SC.

G.T. Jannik presented "1994 Savannah River Site Radioactive Releases and Potential Offsite Doses" at the Radiological Environmental Monitoring Programs (Data Exchange) meeting hosted by SRS.

Miles Denham presented a talk at the 1995 International Association of Hydrogeologist's Congress (solutions '95) in Edmonton, Alberta. The talk entitled "The speciation of Groundwater Contaminated with Coal Pile Leachate at the Savannah River Site, south Carolina" was a summary of the preliminary results of the characterization of D-Area groundwater for the Mag*Sep demonstration and the Coal Pile Initiative Program. A paper of the the same title, co-authored by Ralph Nichols, will be published as part of the the Proceedings of the congress.
Seaman, J., P. Breast, and W. Miller, Colloidal Materials Investigations: The Savannah River Ecology Laboratory has completed a report on year-to-date research on colloid transport. The report entitled "Colloid and Ionic Trace Migration within SRS Sediments, Final Summary" is part of a continuing effort to characterize colloids and colloid migration in the vicinity of $\mathrm{F} / \mathrm{H}$-Area Seepage Basins and has widespread applications to other waste sites and groundwater contamination plumes on site.

D. M. Beals attended the 1995 Pittsburgh Conference in New Orleans and presented a paper titled "Supercritical Fluid Extraction of Trace Metals and Actinides from Solid Matrices" (WSRC-MS-94-0408X). The paper was co-authored by P. R. Cable and S. S. Smalley of ETS (trip report SRT-ETS-95-148).

P. R. Cable attended the 1995 Pittsburgh Conference in New Orleans and presented a paper titled "Glow Discharge Device as a Complementary Source for an ICP Mass Spectrometer" (WSRC-MS-94-0409X). The paper was co-authored by D. M. Beals.

D. M. Beals attended the 209th ACS Meeting in Anaheim, CA, and presented a paper titled "Determination of Technetium-99 and Iodine129 by Inductively Coupled Plasma Source Mass Spectrometry" (trip report SRT-ETS-95250).

W.G. Winn presented "Gamma Well-Logging at the Old Burial Ground of SRS", at the Spring '95 REMP Meeting, Savannah River Site.

"Meteorological Monitoring at the Savannah River Site and New Instrumentation in Meteorology" was presented by M. J. Parker as part of the WSRC Traveling Lecturer Program at the University of Michigan for the faculty/graduate students of the Environmental Health Sciences Program.

"Numerical Simulation of Nocturnal Drainage Flows in an Idealized Valley-Tributary System" was presented at the ANS Fifth Topical Meeting on Emergency Preparedness and Response in Savannah, Georgia, by B. Lance O'Steen. 
Nelson, E.A., W.H. McKee and C. Dulohery. 1995. Restoration of a forested wetland ecosystem in a thermally impacted stream corridor. Presentation and Abstract: National Interagency Workshop on Wetlands, April 3-7, 1995. New Orleans, LA.

Wike, L.D., J.B. Gladden, H.E. Mackey and V.A. Rogers. 1995. Restoration of Lost Lake, recovery of an impacted Carolina Bay (U). Presentation and Abstract: National Interagency Workshop on Wetlands, April 3-7, 1995. New Orleans, LA.

May 9-12, Mark Van Alstine participated in the American Society of Mechanical Engineers course "ASME Boiler and Pressure Vessel Code: Section III, Division 1." The course was held in Pittsburgh, Pennsylvania. The course presented a historical overview of the nuclear code. Rather than a how-to design course, organizational and managerial considerations were discussed.

May 11-12, R. C. Tuckfield traveled to Washington, DC and presented a paper at the Air and Waste Management Conference.

May 16-17, T. L. Spatz traveled to Ellenton Middle School as a participant in the Traveling Science Demonstration Program.

May 21-26, Hanford TCAAP Participation: At the request of DOE EM-261, Mark Van Alstine participated in the Transportation Compliance Assessment/Assistance Program (TCAAP) review of Westinghouse Hanford Company (WHC) hazardous materials transportation and packaging operations. The ten-person TCAAP team objective was to assess WHC compliance with $\mathrm{DOE}$, federal and state requirements and to assist WHC to better comply if necessary. EM261 will provide DOE-Richland the TCAAP report which documents findings and assistance activities. TCAAP participation provided WSRC exposure in the larger DOE arena, organizational insights, and better networking between DOE and contractor personnel.

May 22-23, J. R. Pelfrey attended the National Center for Manufacturing Sciences (NCMS) Conference in Orlando, Florida.
May 22-23, A. C. Smith traveled to Hanford, Washington and attended the Project S-5991, Radioactive Liquid Transport Cask System Procurement Meeting with a follow up technical session on the 24th. The meeting concluded with a memorandum of understanding between WSRC and WHC for procurement of the Liquid Transport Packaging, should WSRC decide to transfer the liquids.

May 31, P. K. Paul gave a presentation entitled "Simulation Modeling of the Savannah River Site's Radioactive Waste Complex" at the Ohio State University's Nuclear Engineering Program's Seminar.

May 31, E. K. Opperman was appointed to the Integration Working Group (IWG) Transportation Focus Group and attended an organizational meeting in Washington DC. This newly formed EM -15 group will address Plutonium Stabilization transportation issues.

\section{Patents:}

K. J. Hofstetter, "Composition and Apparatus for Detecting Gamma Radiation" Patent No. 5,336,889 awarded August 9, 1994.

Publications:

Hook, D.D, B. Davis, J. Scott, J. Struble, C. Bunton and E. A. Nelson. 1995. Locating delineated wetland boundaries in Coastal South Carolina using Global Positioning Systems. Wetlands 15(1): 31-36.

Hofstetter, K. J., "Aerial Robotic Data Acquisition System", Journal of Radioanalytical and Nuclear Chemistry, Vol 193, No. 1, 89-92 (1995)

Addis, R. P., D. P. Griggs, and J. D. Fast. "Prognostic Modeling of Atmospheric Pollutant Transport in Europe" American Nuclear Society's Fifth Topical Meeting on Emergency Preparedness and Response in Savannah, GA.

Paller, M.H. and B.M. Saul. 1995. Effects of temperature gradients resulting from reservoir discharge on Dorosoma cepedianum spawning in the Savannah River. Accepted for publication in Environmental Biology of Fishes. 